\title{
Proneurotrophin-3 Is a Neuronal Apoptotic Ligand: Evidence for Retrograde-Directed Cell Killing
}

\author{
Hiroko Yano, ${ }^{1}$ Risa Torkin, ${ }^{2,3 *}$ Laura Andrés Martin, ${ }^{2 \star}$ Moses V. Chao, ${ }^{1}$ and Kenneth K. Teng ${ }^{2}$ \\ ${ }^{1}$ Molecular Neurobiology Program, Skirball Institute of Biomolecular Medicine, New York University School of Medicine, New York, New York 10016, \\ ${ }^{2}$ Department of Medicine, Weill Cornell Medical College, New York, New York 10065, and ${ }^{3}$ Cell Biology Program, The Hospital for Sick Children, Toronto, \\ Ontario M5G 1X8, Canada
}

\begin{abstract}
Although mature neurotrophins are well described trophic factors that elicit retrograde survival signaling, the precursor forms of neurotrophins (i.e., proneurotrophins) can function as high-affinity apoptotic ligands for selected neural populations. An outstanding question is whether target-derived proneurotrophins might affect neuronal survival/death decisions through a retrograde transport mechanism. Since neurotrophin-3 (NT-3) is highly expressed in non-neural tissues that receive peripheral innervation, we investigated the localized actions of its precursor (proNT-3) on sympathetic neurons in the present study. Pharmacological inhibition of intracellular furin proteinase activity in 293T cells resulted in proNT-3 release instead of mature NT-3, whereas membrane depolarization in cerebellar granule neurons stimulated endogenous proNT-3 secretion, suggesting that proNT-3 is an inducible bona fide ligand in the nervous system. Our data also indicate that recombinant proNT-3 induced sympathetic neuron death that is $\mathrm{p} 75^{\mathrm{NTR}}$-and sortilin-dependent, with hallmark features of apoptosis including JNK (c-Jun N-terminal kinase) activation and nuclear fragmentation. Using compartmentalized culture systems that segregate neuronal cell bodies from axons, proNT-3, acting within the distal axon compartment, elicited sympathetic neuron death and overrode the survival-promoting actions of NGF. Together, these results raise the intriguing possibility that dysregulation of proneurotrophin processing/release by innervated targets can be deleterious to the neurons projecting to these sites.
\end{abstract}

\section{Introduction}

Proneurotrophins are the precursors of a small family of peptide growth factors that include nerve growth factor (NGF), brainderived neurotrophic factor (BDNF), neurotrophin-3 (NT-3), and neurotrophin-4 (NT-4). Until recently, fully processed mature neurotrophins were believed to be the sole ligands responsible for their diverse actions in and outside of the nervous system (Lewin and Barde, 1996; Segal, 2003; Gentry et al., 2004; Teng and Hempstead, 2004). However, both NGF and BDNF precursors can be released as soluble ligands with distinct biological activities (Lee et al., 2001; Nykjaer et al., 2004; Pang et al., 2004; Teng et al., 2005; Woo et al., 2005; Nagappan et al., 2009; Yang et al., 2009a). This supports a paradigm in which proneurotrophins and their mature counterparts interact with distinct coreceptor complexes, thereby inducing diametrically opposite cellular responses. Thus, mature neurotrophins activate the Trk receptor tyrosine kinases

\footnotetext{
Received May 1, 2009; revised Sept. 1, 2009; accepted 0ct. 13, 2009.

This work was supported in part by National Institutes of Health Grants NS21072 and HD23315 (M.V.C.) and NS057627 (K.K.T.) and The James Birrell Neuroblastoma Fund at the Hospital for SickChildren (R.T.) (R.T. was at Weill Cornell Medical College at the time of the study). We are grateful to Dr. Barbara Hempstead for her advice and generous support. We thank Dr. Francis Lee for helpful discussion, Dr. Robert Campenot for sharing his expertise on compartmentalized culture system, and Drs. Anders Nykjaer and Claus Munck Petersen for communicating their unpublished data. We also thank Taeho Kim for his advice on proneurotrophin immunoprecipitation.

${ }^{*}$ R.T. and L.A.M. contributed equally to this work.

Correspondence should be addressed to Kenneth K. Teng, Weill Cornell Medical College, Room D602, 1300 York Avenue, New York, NY 10065. E-mail: kkteng@med.cornell.edu.

H. Yano's present address: Brigham and Women's Hospital, Harvard Medical School, Boston, MA 02115.

R. Torkin's present address: Acorda Therapeutics, Hawthorne, NY 10532.

DOI:10.1523/JNEUROSCI.2059-09.2009

Copyright $\odot 2009$ Society for Neuroscience ～0270-6474/09/2914790-13\$15.00/0
}

to elicit well defined signal transduction cascades, whereas an unrelated $\mathrm{p} 75^{\mathrm{NTR}}$ receptor serves to restrict the fidelity of ligand binding to cognate Trk receptor (Segal, 2003; Gentry et al., 2004; Teng and Hempstead, 2004). In contrast, proNGF and proBDNF engage $\mathrm{p} 75^{\mathrm{NTR}}$ and the vps10p domain-containing receptor sortilin (Nykjaer et al., 2004; Teng et al., 2005; Willnow et al., 2008), with both ligands exerting proapoptotic actions on peripheral and central neurons (Lee et al., 2001; Nykjaer et al., 2004; Teng et al., 2005; Volosin et al., 2006; Jansen et al., 2007).

NT-3 was identified as the third neurotrophin family member, based on sequence conservation with NGF and BDNF (Maisonpierre et al., 1990a). Early in vitro work demonstrated that NT-3 promotes the survival of neuronal subpopulations (Maisonpierre et al., 1990a; Lamballe et al., 1991) and that it is retrogradely transported by both peripheral and central neurons (DiStefano et al., 1992), consistent with its role as a target-derived neurotrophic factor. Compared with other neurotrophins, NT-3 exhibits the most widespread distribution in non-neuronal tissues, including many targets of sympathetic and sensory innervations (Schecterson and Bothwell, 1992; Katoh-Semba et al., 1996, 1998). In vivo studies of gene targeted animals deficient in NT-3 or it receptor TrkC also support important functions for this ligand in peripheral and CNS development (Minichiello and Klein, 1996; Bates et al., 1999; Kahn et al., 1999; Ma et al., 2002; von Bohlen und Halbach et al., 2003). Although it is well known that $\mathrm{p} 75^{\mathrm{NTR}}$ modulates the specificity of NT-3 binding to TrkA-C (Bibel et al., 1999; Mischel et al., 2001; Kuruvilla et al., 2004), activation of $\mathrm{p}^{\mathrm{NTR}}$ alone by NT-3 has also been shown to induce cell death (Friedman, 2000; Wang et al., 2000). Together, 
these findings are consistent with the hypothesis that NT-3 selectively uses different receptor complexes to achieve distinct biological endpoints.

Similar to other neurotrophins, NT-3 is synthesized as a highmolecular-weight precursor (proNT-3) that undergoes furin/ proconvertase-mediated cleavage for its release as a mature dimer (Seidah et al., 1996). Interestingly, perturbation of processing results in proNT-3 secretion instead of mature NT-3 (Seidah et al., 1996; Farhadi et al., 2000). Given the study by Ginty and colleagues (Kuruvilla et al., 2004) that NT-3 acts as an intermediate target-derived neuritogenic factor for innervating sympathetic fibers, we explored the possibility that locally released proNT-3 might elicit alternative action on sympathetic neuron development and provide evidence for target-derived proNT-3 as a retrograde apoptotic ligand.

\section{Materials and Methods}

Cell lines. HEK 293T cells were maintained in DMEM supplemented with $10 \%$ fetal bovine serum, $1 \%$ penicillin/streptomycin, and $1 \%$ pyruvate. Parental PC12 cells and PC12 ${ }^{\mathrm{nnr} 5}$ (Green et al., 1986) were maintained in DMEM, $10 \%$ calf serum, $5 \%$ horse serum, $1 \%$ penicillin/streptomycin, and $1 \%$ pyruvate.

Generation of expression vectors and recombinant proNT-3 protein. $\mathrm{Hu}-$ man full-length preproNT-3 cDNA was amplified by PCR using primers to introduce a $5^{\prime}$ SacI site with an optimized Kozak consensus for translational initiation, and a heptahistidine $\left(\mathrm{His}_{7}\right)$ tag, stop codon, and BamHI site at the $3^{\prime}$ terminus. In parallel, point mutation of KR to AA (amino acid 137, 138; according to GenBank accession number NP_002518) was performed using PCR-based mutagenesis to generate cleavage-resistant proNT-3 cDNA. Constructs encoding native or cleavage-resistant $\mathrm{His}_{7}$-tagged proNT-3 cDNAs, subcloned in pBluescript II SK (pBS NT-3-His ${ }_{7}$ or pBS proNT-3-His ${ }_{7}$, respectively), were bidirectionally sequenced. Next, recombinant baculoviral expression vectors encoding native or cleavage-resistant $\mathrm{His}_{7}$-tagged proNT-3 cDNA were generated using the Bac-to-Bac Baculovirus Expression System by subcloning a PstI-EcoRI insert from pBS NT-3-His ${ }_{7}$ or pBS proNT-3-His 7 into pFastBac I vector. Baculoviral stocks were amplified and propagated using Spodoptera frugiperda (Sf9) cells cultured in Sf-900 II SFM for 72 h, whereas High Five cells cultured in Express Five SFM were used for protein purification. All baculovirus expression system related reagents and cells were purchased from Invitrogen.

For mammalian expression studies, native and cleavage-resistant preproNT-3 cDNAs were PCR-subcloned into pCMV-Tag 4a vector (Stratagene) using the above described $5^{\prime}$-primer and a separate $3^{\prime}$ primer that removes the NT-3 stop codon to generate C-terminal FLAGtagged version of both molecules. The resulting constructs were bidirectionally sequenced.

Purification of $\mathrm{His}_{7}$-tagged recombinant proNT-3 and mature NT-3. Cellular lysates from baculovirus-infected High Five cells (5 multiplicities of infection; $60 \mathrm{~h}$ after infection) were prepared in a detergent-free lysis buffer consisting of $50 \mathrm{~mm}$ Na-phosphate, pH 7.8, $300 \mathrm{~mm} \mathrm{NaCl}, 20$ mM imidazole plus proteinase inhibitors and were used as sources. $\mathrm{His}_{7}$ tagged proNT-3 or mature NT-3 was purified by $\mathrm{Ni}^{+}$ion chromatography (ProBond resins) according to the manufacturer's instruction (Invitrogen). Briefly, after washing in $50 \mathrm{~mm} \mathrm{Na-phosphate,} \mathrm{pH} 7.8,300$ $\mathrm{mm} \mathrm{NaCl}, 20 \mathrm{~mm}$ imidazole, proNT-3-His 7 or mature NT-3-His ${ }_{7}$ was eluted with $50 \mathrm{~mm} \mathrm{Na}$-phosphate, $\mathrm{pH} 7.8,300 \mathrm{~mm} \mathrm{NaCl}$, and $500 \mathrm{~mm}$ imidazole, and were collected in $1 \mathrm{ml}$ fractions. Purification was monitored by Western blot analysis using an anti-NT-3 antiserum that recognizes both proNT-3 and mature NT-3 (sc-547; Santa Cruz Biotechnology) and by silver staining. Fractions containing purified recombinant proteins were pooled and dialyzed against three changes of HBSS (Invitrogen) and stored in aliquots at $-80^{\circ} \mathrm{C}$ until use. Final concentrations of purified mature NT-3 and proNT-3 were determined by quantitative Western blot using an anti-NT3 antibody (sc-547) against serial dilutions of recombinant NT-3 (Promega) as standards. All experiments were conducted with $\mathrm{His}_{7}$-tagged proNT-3 and $\mathrm{His}_{7}$-tagged mature NT-3 that were purified and processed at the same time to ensure internal consistence.

TrkC-dependent signaling and neuritogenesis assay. To compare TrkC activation by NT-3 versus proNT-3, PC12 ${ }^{\mathrm{nnr} 5}$ cells (Green et al., 1986) were stably transfected with an expression plasmid encoding full-length TrkC receptor followed by clonal selection in $500 \mu \mathrm{g} / \mathrm{ml}$ G418. Anti-Trk immunoprecipitation of TrkC-expressing $\mathrm{PC} 12^{\mathrm{nnr} 5}$ clones were performed with an anti-Trk antiserum (sc-11; Santa Cruz Biotechnology) followed by anti-phosphotyrosine (sc-7020; Santa Cruz Biotechnology) Western blotting. Total cellular lysates were also Western blotted with an anti-pErk antiserum (Ab 9101; Cell Signaling Technology) to corroborate activation of downstream TrkC-dependent signaling or with combined anti-Erk1/2 antisera (sc-93 and sc-153; Santa Cruz Biotechnology) to verify equality of sample loading.

For neuritogenic assay, PC12 cells were transiently transfected with green fluorescent protein (GFP) with or without full-length TrkC cDNA by Lipofectamine 2000 (Invitrogen). Twenty-four hours later, replica cultures were treated with NGF, mature NT-3, or proNT-3 in DMEM containing $0.1 \%$ FBS. Paraformaldehyde-fixed, GFP-positive PC12 cells with neurites more than two cell body diameters in length were scored as positive $48 \mathrm{~h}$ later. At least 100 cells were counted from randomly chosen fields per culture conditions by an observer blinded to the treatments.

Primary sympathetic neuron cultures and assessment of apoptosis. Dissociated superior cervical ganglion (SCG) neurons were isolated from postnatal day $0(\mathrm{P} 0)$ to $\mathrm{P} 2$ rats. Alternatively, cultured SCG neurons were prepared from $\mathrm{p} 75^{\mathrm{NTR}}$-null mice (Lee et al., 1992) and wild-type control animals. Unless otherwise stated, neurons were plated on laminin-coated Permanox slides and maintained for $7 \mathrm{~d}$ in NGF as described previously (Nykjaer et al., 2004; Teng et al., 2005). On the day of the experiment, replicate cultures were rinsed five times with NGF-free medium (MEM, $10 \%$ FBS, $0.45 \%$ glucose, 2 mm glutamine, $1 \%$ pyruvate, $1 \%$ penicillin/ streptomycin) and treated with either NGF, mature NT-3, proNT-3, or equivalent quantities of diluent (50 mM Na-phosphate, $\mathrm{pH} 7.8,300 \mathrm{~mm}$ $\mathrm{NaCl}, 500 \mathrm{~mm}$ imidazole dialyzed with three changes of HBSS). Where applicable, parallel cultures were concomitantly treated with various antagonists or inhibitors as indicated at the time of ligand addition. After 36-48 h, SCG cultures were processed for terminal deoxynucleotidyl transferase-mediated biotinylated UTP nick end labeling (TUNEL) analysis (Roche Molecular Biochemicals) and counterstained with antineuronal specific $\beta$-tubulin (TuJ1) (Covance) and $4^{\prime}, 6^{\prime}$-diamidino-2phenylindole (DAPI) to visualize nuclei. Apoptotic neurons, identified by TUNEL positivity and/or fragmented nuclei, were scored blinded as to treatment conditions by the observer, and at least 200 cells were counted for each culture condition. Where applicable, statistical analyses (Student's $t$ test) were performed on the indicated paired samples with significance $(p \leq 0.05)$ indicated by an asterisk $\left(^{*}\right)$. For some experiments, SCG cultures were fixed and stained with phospho-c-Jun N-terminal kinase (JNK) or phospho-c-Jun antibodies (both from Cell Signaling Technology) along with TuJ1 and DAPI. Indirect immunofluorescence analysis was performed using the appropriate secondary antibodies to identify apoptotic neurons.

Compartmentalized cultures. Dissociated SCG neurons were plated on collagen-coated $35 \mathrm{~mm}$ tissue culture plates previously seated with a Teflon divider Camp10 (Tyler Research Instruments) and cultured as described previously (MacInnis and Campenot, 2002; Ye et al., 2003) with the following modifications. Freshly plated SCG neuron cultures were treated with 5-fluorodeoxy-uridine for the first $7 \mathrm{~d}$ to eliminate contaminating non-neuronal cells in the center (cell body) compartment. NGF was used at $20 \mathrm{ng} / \mathrm{ml}$ (in MEM containing $0.3 \%$ methylcellulose, $2.5 \%$ FBS, and $0.4 \%$ glucose) in the center compartment and at $100 \mathrm{ng} / \mathrm{ml}$ (in MEM containing $0.3 \%$ methylcellulose, and $0.4 \%$ glucose) in the distal axon compartment to induce axonal outgrowth. Seven to $10 \mathrm{~d}$ later and on visual inspection of the cultures to ensure axonal growth into the distal compartment, NGF was removed from the center compartment and cultures were treated with $100 \mathrm{ng} / \mathrm{ml} \mathrm{NGF}$ exclusively in the distal compartment to enrich for neurons that bear processes in the distal compartment. Another $3 \mathrm{~d}$ later, NGF within the distal compartment was reduced to $10 \mathrm{ng} / \mathrm{ml}$. Twenty-four hours later, $40 \mathrm{~nm}$ orange fluorescent microspheres (Invitrogen) were added (at 1:1000 dilution in 
MEM plus $10 \mathrm{ng} / \mathrm{ml}$ NGF) to the distal axon chamber. Neurons that were viable with active retrograde transport were thus identified by the uptake of fluorescent microspheres into their cell bodies (Ye et al., 2003). Only replica cultures that were retrogradely labeled were used for additional analysis. Where applicable, statistical analyses (Student's $t$ test) were performed on the indicated paired samples with significance $(p \leq 0.05)$ indicated by an asterisk $\left(^{*}\right)$.

Generation of anti-proNT-3 and sortilin antisera. A glutathione $S$-transferase (GST) fusion protein containing the prodomain of human proNT-3 (amino acids 21-136) was generated by PCR subcloning the corresponding DNA fragment into the EcoRI-XhoI sites of pGEX6p-1 vector, followed by IPTG (isopropyl- $\beta$-D-thiogalactopyranoside) induction in bacteria transformant and purification via glutathione-Sepharose chromatography. Rabbit antisera (Ab 19573 and 19574) were produced by repeated immunization with the GST-NT-3 prodomain fusion protein (Pocono Rabbit Farm and Laboratory). High-titer antisera (as well as preimmune control sera from the respective animals) were sequentially purified by negative adsorption to immobilized GST and IgG enriched by protein A-Sepharose chromatography. Additional affinity purification of the 19574 antiserum was performed using conjugated GST-NT-3 prodomain fusion protein. The resulting antisera (referred to as anti-proNT-3) were dialyzed in PBS and stored in aliquots at $-80^{\circ} \mathrm{C}$ before additional characterization.

Full-length human sortilin cDNA was used as a template to generate $\mathrm{His}_{6}$-tagged truncated sortilin lacking the transmembrane and intracellular domain (amino acids 34-757) and subcloned into the pFastBac I baculoviral vector. Baculoviral stocks were amplified and propagated using S. frugiperda (Sf9) cells, whereas High Five cells cultured in Express Five SFM were used for protein purification by Ni-ion chromatography. Rabbit anti-sortilin antiserum was obtained by repeated immunization with purified $\mathrm{His}_{6}$-tagged truncated sortilin ( $\mathrm{Po}$ cono Rabbit Farm and Laboratory) and was further IgG enriched by protein A-Sepharose chromatography. Specificity of the anti-sortilin antiserum was verified by Western blotting against lysates of 293 cells transfected with human sortilin cDNA and compared with a commercial monoclonal antibody against sortilin (anti-NTR3; BD Biosciences) (supplemental Fig. 1, available at www.jneurosci.org as supplemental material).

Tissue preparation for proNT-3/NT-3 Western blot. Initially, we surveyed several different published protocols for neurotrophin extraction from tissues (Katoh-Semba et al., 1996; Zhang et al., 2001; Yang et al., 2009b) but have found great variability in how well proNT-3 and mature NT-3 can be extracted. The following procedure was eventually adopted because it affords the most efficient and reproducible means for proNT-3/ NT-3 recovery from both neural and non-neural sources: Freshly dissected tissues from rats were immediately processed in ice-cold tissue lysis buffer [20 mm Tris, pH 7.4, $150 \mathrm{~mm} \mathrm{NaCl,} \mathrm{1 \%} \mathrm{NP-40,} \mathrm{1 \%} \mathrm{Triton}$ X-100, 0.05\% SDS, 10\% glycerol, $1 \mathrm{~mm}$ PMSF, and proteinase inhibitor mixture (Sigma-Aldrich)] (Yang et al., 2009b) using a hand-held tissue homogenizer (Omni International), except that hippocampal lysate was obtained by pooling six to eight dissected hippocampi (kept on dry ice until the end of the dissection) before the homogenization step. Tissue lysates were incubated at $4^{\circ} \mathrm{C}$ with constant shaking for $15 \mathrm{~min}$ and were then cleared by centrifugation at $13,000 \times g$ for $15 \mathrm{~min}$ at $4^{\circ} \mathrm{C}$ before
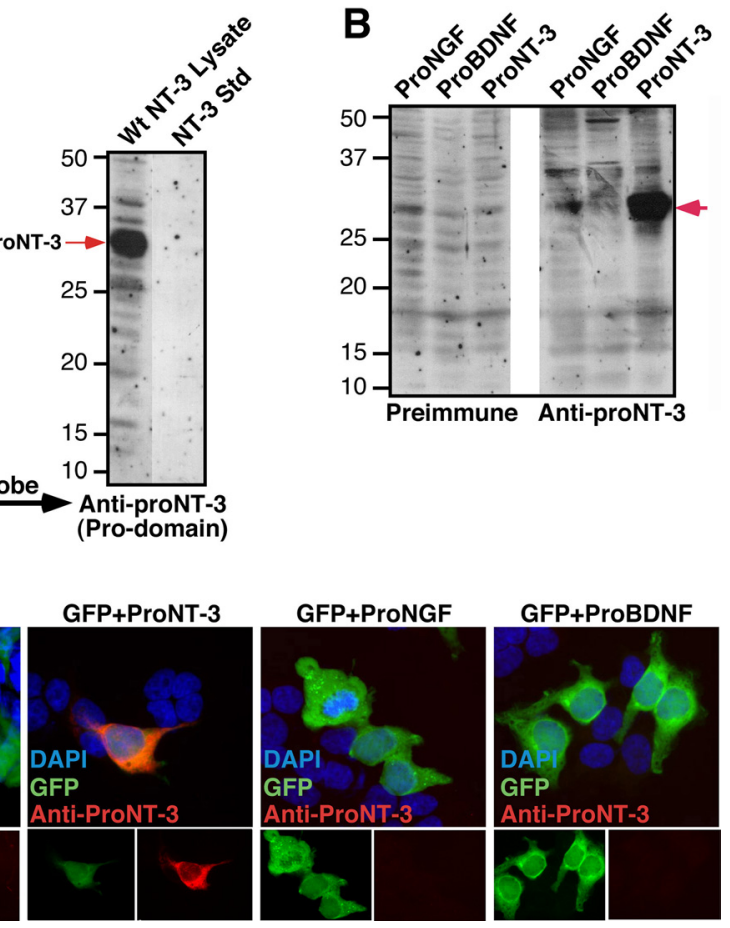

Figure 1. Characterization of anti-proNT-3 antiserum. $\boldsymbol{A}$, Sf9 cells expressing full-length preproNT-3 cDNA synthesize both proNT-3 and mature NT-3 as indicated (red arrows). Total cellular lysates, along with recombinant NT-3 standard (Promega), were bloted with an anti-NT-3 antiserum (sc-547; Santa Cruz Biotechnology) followed by reprobing the blot with an antion the left indicate positions of the molecular weight markers. $\boldsymbol{B}$. Western blot of Sf 9 cells expressing proNGF, proBDNF, or proNT-3 proN, and the numbers on the left indicate positions of the molecular weight markers. C, HEK 293T cells were cotransfected with proNT-3 antibody. The top panels represent merged images (with DAPI) of GFP epifluorescence and preimmune or proNT-3 immunoreactivity (bottom insets) from the corresponding transfected cells.

Bradford-based quantitation (Bio-Rad Laboratories). Aliquoted samples (in $1 \times$ SDS-PAGE buffer) were boiled and immediately stored at $-80^{\circ} \mathrm{C}$ before additional analysis.

Western blotting analysis of proNT-3 and mature NT-3 expression in various tissues was performed as described previously (Randolph et al., 2007) using PVDF (polyvinylidene difluoride) membrane in $8 \%$ nonfat dry milk with a rabbit anti-NT-3 antibody (sc-547; Santa Cruz Biotechnology; 1:1000 dilution). To demonstrate specificity, the anti-NT-3 antiserum was pretreated with 100 -fold molar excess of recombinant NT-3 (Promega) for $1.5 \mathrm{~h}$ at $25^{\circ} \mathrm{C}$ in PBS before using it for Western blotting (Randolph et al., 2007). As a control, anti-NT-3 antiserum that did not receive recombinant NT-3 was processed in parallel before use.

Endogenous proNT-3 immunoprecipitation. Dissociated P6 cerebellar granule neurons were cultured on poly-L-lysine-coated $150 \mathrm{~mm}$ tissue culture plates and maintained in MEM supplemented with $10 \%$ fetal bovine serum, $25 \mathrm{~mm} \mathrm{KCl}, 2 \mathrm{~mm}$ GlutaMax, $0.45 \%$ glucose, $1 \%$ penicillin/streptomycin, and $1 \%$ pyruvate. Cultures were also treated with 5 -fluorodeoxy-uridine for the first $3 \mathrm{~d}$ to eliminate contaminating nonneuronal cells. On day in vitro (DIV) 6 , cultured granule neurons were rinsed once with Neurobasal medium (containing $1 \times$ B27 supplement, $0.1 \mathrm{mg} / \mathrm{ml}$ bovine serum albumin, and $0.5 \mu \mathrm{M}$ GlutaMax) for $1 \mathrm{~h}$ before treatment with $25 \mathrm{~mm} \mathrm{KCl}$ to stimulate proNT-3 release. Where indicated, the cell-permeable furin inhibitor I (Dec-RVKR-CMK; Calbiochem) was used at $30 \mu \mathrm{M}$. To capture secreted proNT-3, a goat anti-NT-3 antiserum (sc-13380; Santa Cruz Biotechnology) was added to the culture medium (1:100 dilution) at the time of treatment. In addition, to prevent proteolytic degradation of proNT-3, a cell-impermeant $\alpha_{2}$ anti- 
A

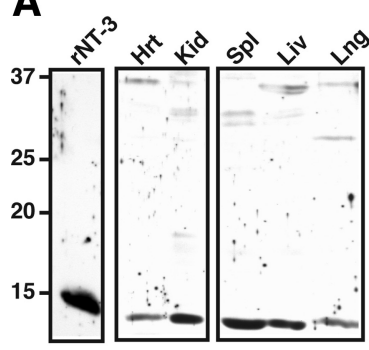

WB: Anti-NT-3

B

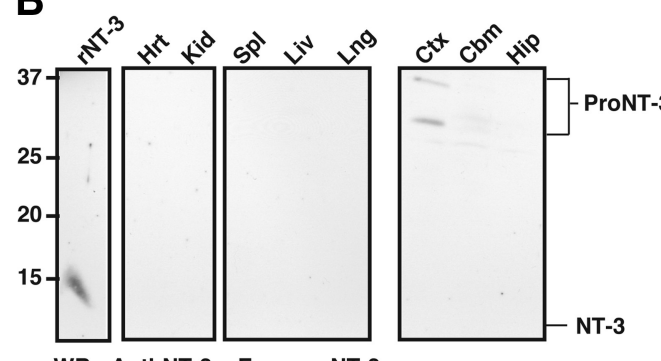

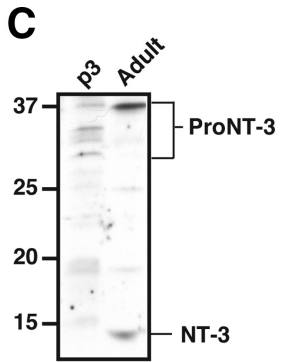

WB: Anti-NT-3

D

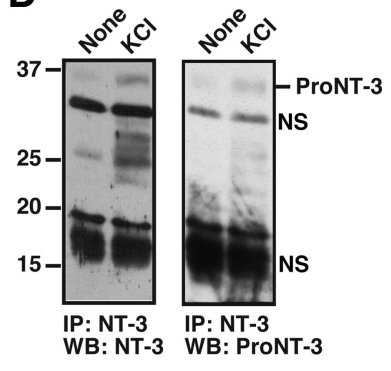

Figure 2. Neuronal release of endogenous proNT-3. $\boldsymbol{A}$, Tissue-specific expression of proNT-3 and mature NT-3. Detergent lysates were prepared from the indicated tissues. Except for heart and kidney in which $100 \mu \mathrm{g}$ of the respective lysates were analyzed, equal amounts of visceral tissue lysates $(50 \mu \mathrm{g})$ and $150 \mu \mathrm{g}$ of CNS tissue lysates were Western blotted with an anti-NT-3 antiserum (sc-547). This was done because the range of proNT-3/NT-3 expression varies greatly between these tissues (Kaisho et al., 1994; Katoh-Semba et al., 1996); the resulting enhanced chemiluminescence signals would have exceeded the linearity of the film without the loading adjustment. Note that various non-neural and CNS tissues express mature NT-3 and proNT-3 at varying proportion and abundance. The numbers on the left indicate positions of the molecular weight markers. The brackets on the right indicate multiple proNT-3 species whose identities were confirmed by reprobing the blot with anti-proNT-3 antiserum and an independently generated anti-NT-3 antibody (data not shown). Ctx, Cortex; Cbm, cerebellum; Hip, hippocampus; Spl, spleen; Hrt, heart; Lng, lung; Kid, kidney; Liv, liver. $\boldsymbol{B}$, To demonstrate specificity of the proNT-3 and mature NT-3 species, anti-NT-3 antibody (sc-547) was preincubated with excess recombinant NT-3 before addition to a replica tissue lysates blot but was otherwise processed in identical manner as in Figure 2A. C, Age-dependent expression of proNT-3 and mature NT-3. Cerebellar lysates from early postnatal (P3) and adult female rat were Western blotted with anti-NT-3 (sc-547). Positions of proNT-3 and mature NT-3 are indicated on the right. D, P6 cerebellar granule neurons in culture were treated with either $5 \mathrm{~mm} \mathrm{KCl}$ (None) or with $25 \mathrm{~mm} \mathrm{KCl}$ for $24 \mathrm{~h}$ in the presence of a goat anti-NT-3 antibody (sc-13380) as described in Materials and Methods. Anti-NT-3 immunoprecipitates were Western blotted with either rabbit anti-NT-3 antiserum (sc-547; left panel) or with anti-proNT-3 specific antiserum (right panel) to verify the identify of proNT-3. The position of proNT-3 is indicated on the left as are positions of nonspecific bands (NS).

plasmin inhibitor (Calbiochem) was added to all the cultures (Teng et al., 2005). Twenty-four hours later, neuronal conditioned media were collected, cleared of cellular debris by centrifugation, and supplemented with the proteinase inhibitors PMSF, leupeptin, and aprotinin. Protein $\mathrm{A} / \mathrm{G}$-agarose beads (Pierce) were then added to the media for $16 \mathrm{~h}$ to immunoprecipitate proNT-3, followed by three washes in Tris lysis buffer (TLB) containing $20 \mathrm{~mm}$ Tris, $\mathrm{pH} 7.4,150 \mathrm{~mm} \mathrm{NaCl}, 2 \mathrm{~mm} \mathrm{CaCl}$, and $10 \%$ glycerol. To elute captured proNT-3, washed agarose beads were incubated with $0.1 \mathrm{M}$ glycine, $\mathrm{pH} 2.5$, for $10 \mathrm{~min}$ at $4^{\circ} \mathrm{C}$. Eluates were immediately neutralized with $1.5 \mathrm{M}$ Tris, $\mathrm{pH} 8.8$, before addition of $5 \times$ SDS-PAGE sample buffer, followed by Western blotting with anti-NT-3 or anti-proNT-3 antisera.

ProNT-3 and coreceptors immunoprecipitation. HEK 293T cells were transfected with mammalian expression vectors encoding $\mathrm{p} 75^{\mathrm{NTR}}$, and/or Myc-tagged sortilin in the presence or absence of FLAG-tagged cleavage-resistant proNT-3. Forty-eight hours later, cells were harvested in lysis buffer containing $20 \mathrm{~mm}$ Tris, pH 7.4, $150 \mathrm{~mm} \mathrm{NaCl}, 1 \% \mathrm{NP}-40$ supplemented with proteinase inhibitors. To detected intracellular proNT-3 interaction with sortilin, anti-FLAG immunoprecipitates were Western blotted with a rabbit anti-Myc antibody (Abcam) according to standard protocol.

To detect $\mathrm{p} 75^{\mathrm{NTR}}$ and sortilin binding to exogenously added proNT-3, $293 \mathrm{~T}$ cells expressing both, or either, receptor were treated for $1 \mathrm{~h}$ at $37^{\circ} \mathrm{C}$ with conditioned medium (MEM containing 2 mM GlutaMax, $0.45 \%$ glucose, $1 \%$ penicillin/streptomycin, and $1 \%$ pyruvate) from $293 \mathrm{~T}$

cells transfected with FLAG-tagged proNT-3 cDNA. Receptor-expressing cells were then harvested in TLB before overnight immunoprecipitation with a biotinylated goat antip75 ${ }^{\text {NTR }}$ antibody (BAF367; R\&D Systems) using streptavidin beads (Pierce). After five washes in TLB, the receptor-bound proNT-3 was eluted with $0.1 \mathrm{M}$ glycine, $\mathrm{pH} 2.5$, and processed as described above for Western blotting analysis.

\section{Results}

Previous work demonstrated that the precursors of NGF and BDNF (i.e., proNGF and proBDNF, respectively) are secreted ligands with opposing biological actions to their mature neurotrophin counterparts. During development, NT-3 exhibits the highest level of expression among the neurotrophins examined in a variety of target tissues (Maisonpierre et al., 1990b; Katoh-Semba et al., 1996, 1998). Yet it remains unclear whether NT-3 is released as a higher molecular weight form (i.e., proNT-3), and if so, how proNT-3 affects neuronal functions. Therefore, we first sought evidence of endogenous proNT-3 secretion in the present study.

\section{Neuronal release of endogenous proNT-3}

Rabbit antisera, raised against the prodomain of human prepro-NT-3 (referred to as anti-proNT-3), were assessed for reactivity toward proNT-3 but not mature NT-3 or other proneurotrophins. As shown in Figure $1 A$, Sf9 cells infected with a full-length preproNT-3 containing viral vector express both mature NT-3 $(\sim 14.5$ $\mathrm{kDa})$ and the high-molecular-weight proNT-3 ( $\sim 32 \mathrm{kDa})$, based on Western blot analysis using a commercial antiNT-3 antiserum that recognizes the C-terminal portion of both NT-3 and proNT-3. Reprobing the membrane with our antiproNT-3 antiserum revealed only the $32 \mathrm{kDa}$ proNT-3 species. The specificity of the anti-proNT-3 antiserum was confirmed by Western blot analysis of lysates from insect cells expressing either proNGF, proBDNF, or proNT-3. These proteins were generated from expression constructs in which the furin consensus sites of the neurotrophins were mutated to block cleavage (Negro et al., 1994; Seidah et al., 1996; Lee et al., 2001; Teng et al., 2005) (see Fig. $3 A$ ). As shown in Figure $1 B$, immunopositive signal was only detectable from cells that expressed proNT-3. Reprobing the blot with anti-NGF and anti-BDNF antisera confirmed the presence of proNGF and proBDNF, respectively, in the corresponding cell lysates (data not shown). Consistent with the results from Figure $1 B$, proNT-3 antiserum specifically recognizes HEK 293 cells that were transfected with proNT-3, but not proNGF or proBDNF, expression plasmid by immunofluorescence microscopy (Fig. $1 C)$. These results together indicate that our antiserum specifically recognizes the prodomain of proNT-3 with no detectable cross-reactivity to mature NT-3 or other proneurotrophins.

Multiple tissues from newborn rat contain proNT-3 and mature NT-3 at varying abundance and ratios as assessed by anti- 
NT-3 Western blot analysis (Fig. 2A). The specificity of proNT-3 and mature NT-3 immunoreactivity was confirmed by probing replica blot with the same anti-NT-3 antiserum in the presence of excess recombinant NT-3 (Fig. 2 B). Although we cannot rule out the possibility that lower molecular weight proNT-3 isoforms that were present in some of the tissues arose from partial proteolytic degradation during sample preparation, it is noteworthy that proNT-3 of various sizes $(\sim 28-37 \mathrm{kDa})$ have been predicted to exist because of alternative $5^{\prime}$ exon usage as well as multiple in-frame ATG start sites within the NT-3 transcripts (Leingärtner and Lindholm, 1994; Kendall et al., 2000).

Interestingly, representative CNS tissues of $\mathrm{P} 1$ rat appear to express predominantly the high-molecular-weight proNT-3. Although prolonged exposure to film did reveal trace amount of mature NT-3 in these CNS tissues (data not shown), it is apparent that the ratio of proNT-3 to mature NT-3 is significantly greater in the developing CNS, compared with visceral organs of the same age. In contrast, mature NT-3 is readily detectable in the adult brain. As shown in Figure $2 C$, both proNT-3 and mature NT-3 are present in the cerebellum of older animals, consistent with a recent finding that the relative expression of proBDNF and mature BDNF is developmentally regulated (Yang et al., 2009b).

Past studies have documented a high level of NT-3 expression in the cerebellum (Lindholm et al., 1993; Katoh-Semba et al., 1998) and activity-dependent release of NT-3 from cultured cerebellar granule neurons (Sadakata et al., 2004, 2007). These ELISA-based assays, however, did not distinguish whether proNT-3 or mature NT-3 is secreted. Since cerebellum expresses mostly proNT-3 at early postnatal age (Fig. $2 A$ ), we performed anti-NT-3 immunoprecipitation analysis from conditioned media of $\mathrm{KCl}$-depolarized cultured cerebellar granule neurons (Fig. $2 D)$ to directly examine whether proNT-3 is released in an activitydependent manner. Our data indicate that, under basal culture condition, there was negligible proNT-3 release from P6 granule neurons. However, on membrane depolarization, a significant amount of proNT-3 can be detected in the media of these cultures.

\section{Purification of recombinant proNT-3}

Previous work used the baculoviral-insect cell system to purify biologically active mature NT-3 and has provided indirect evidence of $\mathrm{R}^{138}: \mathrm{Y}^{139}$ as the site of proNT-3 cleavage to yield mature NT-3 (Negro et al., 1994). To assess the potential roles of proNT-3 within the nervous system, we generated a recombinant proNT-3 mutant in which the putative furin/proconvertases cleavage motif has been mutated $\left(\mathrm{K}^{137} \mathrm{R}^{138} \rightarrow \mathrm{A}^{137} \mathrm{~A}^{138}\right)$. As shown in Figure 3A, HEK 293T cells transfected with epitopetagged wild-type preproNT-3 cDNA were able to process and release mature NT-3 into the culture medium. Consistent with past findings (Seidah et al., 1996; Farhadi et al., 2000), inhibition of intracellular furin/proconvertase activity by Dec-RVKR-CMK resulted in the secretion of $\sim 35-37 \mathrm{kDa}$ proNT-3 instead of mature NT-3. Importantly, we found that the $\mathrm{K}^{137} \mathrm{R}^{138} \rightarrow \mathrm{A}^{137} \mathrm{~A}^{138}$ mutation completely prevented the conversion of proNT-3 to the mature species. Therefore, $\mathrm{K}^{137} \mathrm{R}^{138}$ appear to be the critical residues that are required for proNT-3 processing to mature NT-3 in mammalian cell system. We also demonstrated that furin inhibitor only modestly augmented proNT-3 secretion from cultured cerebellar neurons in the absence of membrane depolarization (Fig. 3A, left panel), consistent with the data in Figure 2 that proNT-3 is the predominant NT-3 isoform in early postnatal CNS neurons.

Taking advantage of the above findings, baculoviral vectors harboring wild-type or furin cleavage mutant preproNT-3 cDNA
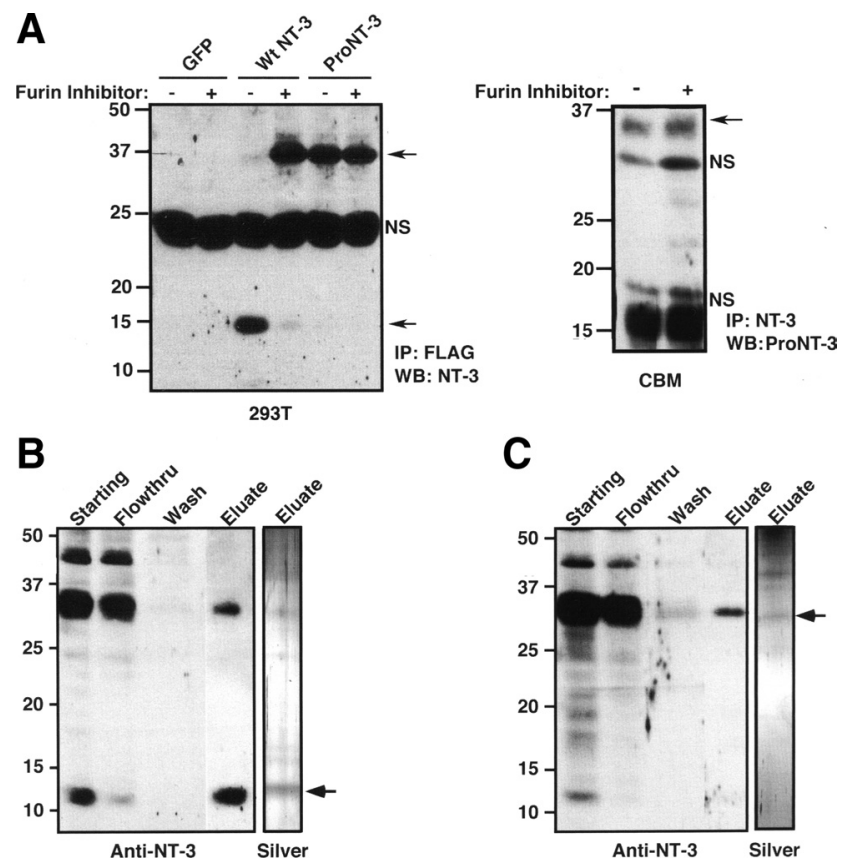

Figure 3. Purification of recombinant NT-3 and furin-resistant proNT-3. $\boldsymbol{A}$, Right panel, HEK 293T cells were transfected with control GFP encoding plasmid or with plasmids encoding FLAG-tagged wild-type NT-3 or proNT-3 in which the putative furin cleavage motif had been mutated. Replica cultures were treated, or not, with $30 \mu \mathrm{m}$ Dec-RVRK-CMK $24 \mathrm{~h}$ after transfection. Conditioned media were immunoprecipitated with anti-FLAG antiserum (M2; SigmaAldrich) after another $48 \mathrm{~h}$. Immunoprecipitates were then analyzed by Western blotting using a commercial anti-NT-3 antiserum (sc-547). Left panel, Cultured cerebellar granule neurons were treated or not with $30 \mu \mathrm{m}$ furin inhibitor Dec-RVKR-CMK for $24 \mathrm{~h}$ as indicated. Conditioned media were immunoprecipitated with a goat anti-NT-3 antiserum followed by proNT-3 Western blotting as described (see Materials and Methods). Position of proNT-3 is indicated on the left as are position of nonspecific bands (NS). $\boldsymbol{B}$, His $_{7}$-tagged mature NT-3 from lysates of insect cells infected with wild-type preproNT-3-His ${ }_{7}$ encoding baculoviral vector was purified as described in Materials and Methods. C, Purification of $\mathrm{His}_{7}$-tagged proNT-3 from lysates of insect cells infected with cleavage resistant proNT-3-His $\boldsymbol{H}_{7}$ encoding baculoviral vector. For $\boldsymbol{B}$ and $\boldsymbol{C}$, the extent of purification was monitored by anti-NT-3 Western blot analysis of equal proportion ( $1 / 200$ by volume) of each indicated fractions and by silver staining of the NT-3- and proNT-3enriched eluates. The numbers on the left indicate positions of the molecular weight markers. Where appropriate, arrows mark the positions of proNT-3 and mature NT-3.

with an in-frame C-terminal $\mathrm{His}_{7}$ tag were used for mature NT-3 or proNT-3 production, respectively, in the insect High Five cells. After Ni-ion chromatography and anti-NT-3 Western blot analysis (Fig. $3 B$ ), purified mature $\mathrm{His}_{7}$-tagged NT-3 was detectable at the predicted molecular weight $(\sim 14 \mathrm{kDa})$ with the minor presence of a higher molecular species $(\sim 30 \mathrm{kDa})$; presumably, a small fraction of proNT-3 has escaped cleavage because of overexpression (Negro et al., 1994). In contrast, eluates from cells expressing the furin cleavage proNT-3 mutant contain exclusive the $\sim 30 \mathrm{kDa}$ proNT-3 species (Fig. 3C) that was recognized by the anti-proNT-3 antibody (data not shown).

\section{Dual-receptor requirement for proNT-3 apoptotic actions}

To assess the biological actions of proNT-3, we examined whether recombinant proNT-3 exhibits similar activity as mature NT-3 in mediating TrkC-specific signal transduction. A PC12 mutant cell line that does not express the NGF-responsive TrkA receptor (PC12 ${ }^{\mathrm{nnr} 5}$ ) (Green et al., 1986) was stably transfected with full-length TrkC. As shown in Figure $4 A$, treatment of the TrkC-expressing PC12 ${ }^{\text {nnr5 }}$ cells with NT-3, but not proNT-3, resulted in TrkC tyrosine phosphorylation as well as in p42/p44 mitogen-activated protein (MAP) kinase activation. As expected, 
A
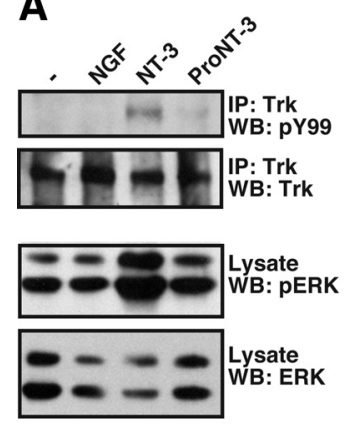

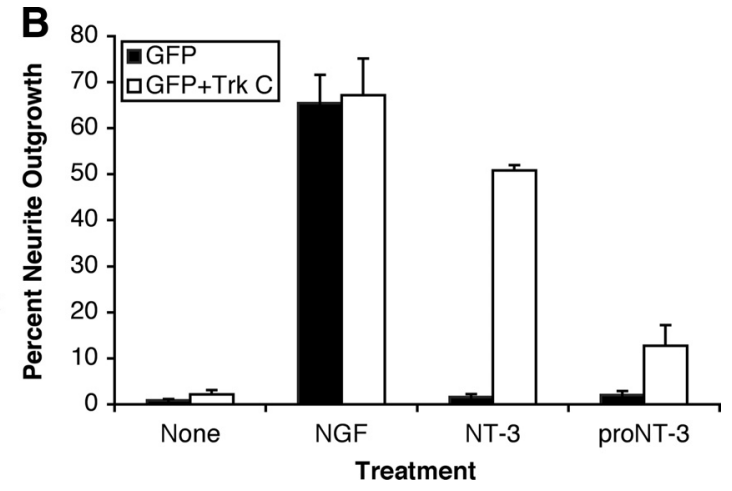

Figure 4. ProNT-3 does not activate TrkC. $A$, TrkA-deficient $\mathrm{PC} 12^{\mathrm{nnr5}}$ cells were transfected with a mammalian TrkC expression plasmid (Klein et al., 2005) followed by $500 \mu \mathrm{g} / \mathrm{ml}$ G418 selection to obtain TrkC-PC12 ${ }^{\mathrm{nnr} 5}$ cell clones. Serum-starved TrkCPC12 ${ }^{\mathrm{nn} 5}$ cells were treated, or not, with $100 \mathrm{ng} / \mathrm{ml} \mathrm{NGF}, 25 \mathrm{ng} / \mathrm{ml}$ mature NT-3, or $25 \mathrm{ng} / \mathrm{ml}$ proNT-3 for 10 min as indicated. Detergent-extracted cellular lysates were immunoprecipitated with an anti-Trk antiserum followed by anti-phosphotyrosine Western blotting to assess TrkC activation. The blot was then reprobed with an anti-Trk antiserum to verify the presence of Trk in all the samples. In addition, whole-cell lysates were Western blotted with pERK or total ERK antibody to demonstrate ERK activation by NT-3, but not proNT-3, in TrkC-PC12 ${ }^{\text {nnr5 }}$ cells. $\boldsymbol{B}$, Wild-type PC12 cells were transiently transfected with expression plasmids encoding GFP (to mark transfected cells) with or without TrkC. Forty-eight hours later, replica cultures were treated or not with 20 $\mathrm{ng} / \mathrm{ml} \mathrm{NGF}$, and equal molar of NT-3 or proNT-3 (i.e., $20 \mathrm{ng} / \mathrm{ml} \mathrm{NT}-3$ or $40 \mathrm{ng} / \mathrm{ml} \mathrm{proNT}-3$ ) as indicated. The percentage of neurite-bearing populations were assessed $48 \mathrm{~h}$ later as described (see Materials and Methods). Data represent the results obtained from two independently conducted experiments. Error bars indicate ranges of values from two independent experiments.

abrogated by Trk receptor activation (Volosin et al., 2006). The underlying mechanism that differentiates these cell typespecific responses is presently unclear.

Having identified proNT-3 as a proapoptotic ligand, we further compared the relative effectiveness of proNT-3 with other previous described triggers of sympathetic neuron death. Our data demonstrate that proNT-3, at comparable concentrations $(0.1 \mathrm{nM})$, is as effective as proNGF in inducing SCG apoptosis (Fig. 5C) (Nykjaer et al., 2004). Likewise, under mildly depolarizing condition, high concentration of BDNF (2 nM) (Bamji et al., 1998) and proNT-3 (0.1 nM) were able to promote SCG neuron death to similar extent (Fig. 5D).

The data from Figure 5 are consistent with a role for proNT-3 as a high-affinity neuronal apoptotic ligand. Its biological effect is thus reminiscent of the recently identified dual receptor mechanism for proneurotrophin actions (Lee et al., 2001; Nykjaer et al., 2004; Teng et al., 2005;

NGF did not elicit downstream signaling in these cells. Consistent with the data from Figure $4 A$, transient expression of TrkC in wild-type (NGF-responsive) PC12 cells imparts NT-3 responsiveness (Fig. $4 \mathrm{~B}$ ). In contrast, proNT-3 treatment did not induce significant neurite extension in TrkC-expressing PC12 cells. As positive controls, NGF-elicited neurite outgrowth was observed in GFP-transfected or TrkC-transfected PC12 cells. Together, these data suggest that proNT-3 does not promote neuronal differentiation via TrkC.

As past studies have demonstrated that high concentrations (50-100 ng/ml; i.e., 1-2 nM) of mature NT-3 triggered apoptosis in a p $75^{\mathrm{NTR}}$-dependent manner in hippocampal neurons (Friedman, 2000) and a smooth muscle cell line (Wang et al., 2000), we next asked whether proNT-3 can induce cell death and, if so, which receptor(s) are required for this action. Sympathetic neurons from the SCGs have been a well characterized model system for analysis of p $75^{\mathrm{NTR}}$-mediated apoptotic signaling (Bamji et al., 1998; Palmada et al., 2002; Kenchappa et al., 2006). To examine whether proNT-3 induces SCG neuron death, replica cultures of rat sympathetic neurons were deprived of NGF in the presence or absence of recombinant cleavage resistant proNT-3. Assessment of TUNEL positivity and nuclear morphology revealed that proNT-3, at subnanomolar concentrations, significantly increased the proportion of neuronal apoptosis when compared with non-proNT-3 treated (but NGF-deprived) controls (Fig. $5 A$ ). Consistent with the finding that sympathetic neuron survival per se is NT-3 independent (Kuruvilla et al., 2004), mature NT-3, when applied at identical concentration to that of proNT-3 $(0.1 \mathrm{nM})$, did not enhance or reduce apoptosis of the NGFdeprived cultures.

We also found that subnanomolar concentrations of NGF effectively rescued proNT-3-treated SCG neurons from dying, suggesting that activation of the TrkA receptor in these cells can counter the apoptotic actions of p $75^{\mathrm{NTR}}$, consistent with past findings in NGF-treated oligodendrocytes (Yoon et al., 1998) and in proBDNF-treated sympathetic neurons (Teng et al., 2005). These data are in contrast, however, to the study in basal forebrain neurons in which proneurotrophin elicited death was not
Jansen et al., 2007). We therefore considered whether both p $75^{\text {NTR }}$ and sortilin are required for proNT-3 apoptotic actions. As shown in Figure $6 \mathrm{~A}$, coexpression of FLAG-tagged proNT-3 with Myc-tagged sortilin in HEK 293T cells resulted in complex formation between these two components as detected by antiFLAG immunoprecipitation and anti-Myc Western blot analysis. Surprisingly, we were unable to detect a stable complex between p $75^{\text {NTR }}$ and proNT-3 nor did the coexpression of sortilin augment $\mathrm{p} 75^{\mathrm{NTR}}$-proNT-3 interaction by coimmunoprecipitation analysis from cellular lysates, suggesting that the biosynthetic pathways of ectopically expressed $\mathrm{p} 75^{\mathrm{NTR}}$ and proNT-3 do not overlap. Therefore, to functionally assess whether both $\mathrm{p} 75^{\mathrm{NTR}}$ and sortilin are required for proNT-3 binding, we transfected these two receptors, alone or in combination, in $293 \mathrm{~T}$ cells followed by exogenous proNT-3 treatment. As shown in Figure $6 B$, we were able to detect proNT-3 as well as sortilin in anti-p $75^{\text {NTR }}$ immunoprecipitates from cells that coexpress both $\mathrm{p} 75^{\mathrm{NTR}}$ and sortilin. In addition, NT-3 immunoreactivity was detectable in lysate of these cells as multiple partially cleaved forms, suggesting that proNT-3 binding to $75^{\text {NTR }}$ (and presumably internalization and subsequent degradation) requires sortilin coexpression.

To directly assess the role of $\mathrm{p} 75^{\mathrm{NTR}}$ in proNT-3-elicited neuronal apoptosis, we compared the effects of proNT-3 on SCG cultures derived from $\mathrm{p} 75^{\mathrm{NTR}}$-null mice versus wild-type control animals (Fig. 6C). Consistent with the data obtained with rat SCGs, proNT-3 induced a $\sim 50 \%$ increase in neuronal apoptosis of wild-type mouse SCG cultures. In contrast, treatment of p75 ${ }^{\text {NTR }}$-null SCG neurons with proNT-3 did not enhance cell death, indicating that proNT-3-induced apoptosis occurred in a p75 ${ }^{\text {NTR }}$-dependent manner.

To evaluate whether sortilin is required for proNT-3-induced SCG neuron death, we took advantage of the finding that neurotensin competes with proneurotrophins for sortilin binding (Nykjaer et al., 2004; Teng et al., 2005; Quistgaard et al., 2009) but does not promote survival of NGF-deprived sympathetic neurons (Unsicker and Stögbauer, 1992). Thus, we compared the effects of proNT-3 on SCG neuron survival in the absence or presence of $20 \mu \mathrm{M}$ neurotensin. As shown in Figure $6 D$, neuro- 
tensin effectively abrogated the proapoptotic effect of proNT-3 but did not otherwise display additional survivalpromoting action, consistent with past findings (Unsicker and Stögbauer, 1992; Nykjaer et al., 2004; Teng et al., 2005). Furthermore, an antibody raised specifically against the ectodomain of sortilin was able to block proNT-3-induced cell death (supplemental Fig. 1, available at www.jneurosci.org as supplemental material; Fig. 6E). Together, these data suggest that proNT-3 elicits apoptotic signaling via $\mathrm{p} 75^{\mathrm{NTR}}$ and the coreceptor sortilin.

\section{ProNT-3 activates apoptotic signaling} Past studies on $\mathrm{p} 75^{\mathrm{NTR}}$-mediated signaling identified a number of downstream pathways that play critical roles in cellular apoptosis (Dechant and Barde, 2002; Roux and Barker, 2002; Kenchappa et al., 2006; Volosin et al., 2008). Among them, the stress-induced MAP kinase member JNK has been well described as a p75 ${ }^{\text {NTR }}$ inducible apoptotic kinase (Harrington et al., 2002; Linggi et al., 2005). Since proNT-3 appears to require $\mathrm{p} 75^{\mathrm{NTR}}$ for its apoptotic actions (Fig. $6 B$ ), we questioned whether JNK might be a downstream effector of $\mathrm{p} 75^{\mathrm{NTR}}$ activation by proNT-3. Since NGF deprivation alone results in SCG neuron death and JNK activation (Eilers et al., 1998), the additive effect of proNT-3 on JNK activation, if any, might be masked in such an experimental paradigm. Membrane depolarization prevents sympathetic death on trophic factor withdrawal (Franklin et al., 1995). We therefore asked whether proNT-3 can still induce neuronal apoptosis when NGF-deprived cultures were maintained by $\mathrm{KCl}$. As shown in Figure $7 \mathrm{~A}$ and consistent with past findings, chronic membrane depolarization effectively promotes neuronal survival in the absence of NGF. Importantly, proNT-3, but not mature NT-3, remained effective in triggering SCG apoptosis even under depolarizing condition.

Using this tissue culture paradigm, we assessed whether proNT-3 activates JNK in sympathetic neurons. Replica cultures of NGF-deprived but KCl-maintained neurons were treated with either NGF, NT-3 or proNT-3, or no additive as indicated. Total cellular lysates were harvested $4 \mathrm{~h}$ after treatment and were analyzed by Western blotting analysis using antisera that differentiate survival or apoptotic signaling (Fig. 7B). As expected, NGF, but not NT-3 or proNT-3, stimulated tyrosine phosphorylation of TrkA. In contrast, proNT-3, but not NGF or NT-3, augments JNK phosphorylation, consistent with its apoptotic effects. In concert with the Western blot data, proNT3-treated neurons were strongly positive for $\mathrm{p}$-JNK and $\mathrm{p}$-Jun by immunofluorescent analysis (Fig. 7C). Significantly, the JNK inhibitor anthra [1,9-cd]pyrazol-6(2H)-one (SP600125) completely prevented proNT-3-induced SCG death, suggesting a causal role for JNK as downstream apoptotic effector (Fig. 7D). between the paired samples.
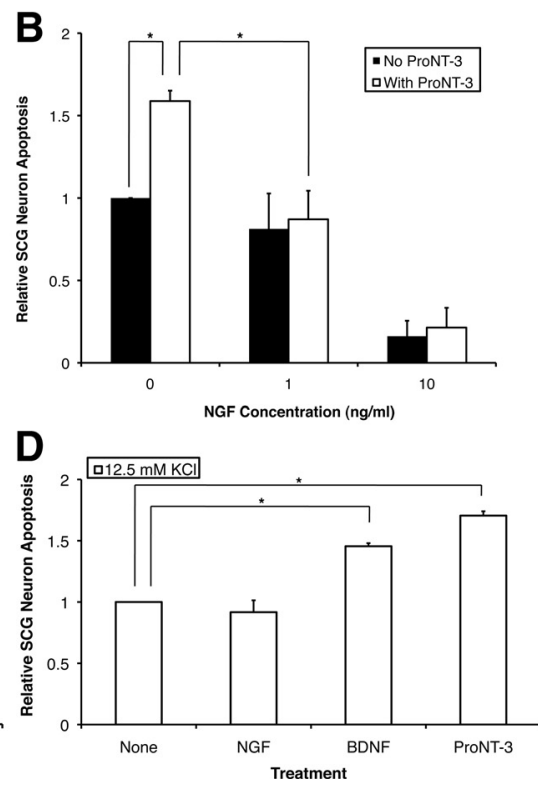
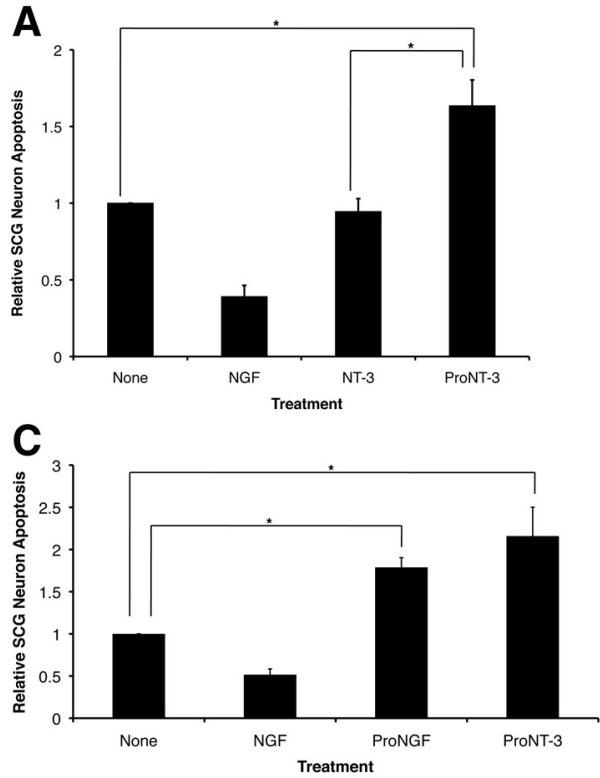

Figure 5. Apoptotic actions of proNT-3.A, P1 rat SCG neurons (DIV 7), washed free of NGF, were treated with no additive (None), $10 \mathrm{ng} / \mathrm{ml} \mathrm{NGF}$, or equal molar of NT-3 or proNT-3 (i.e., $2 \mathrm{ng} / \mathrm{ml} \mathrm{NT}-3$ or $4 \mathrm{ng} / \mathrm{ml}$ proNT-3) as indicated. The percentage of apoptotic

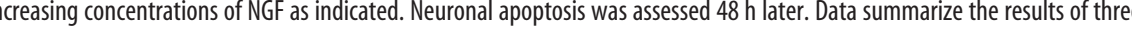
. Pat SCG neurons plated on collagen-coated slides were washed free of NGF on DIV 7 and were then treated with no ent three independently conducted experiments, and the vertical error bars indicate SEM Note that for this particular experiment, SCG neurons were plated on collagen instead of laminin because we found that laminin interferes with the apoptotic Under this culur , condition elicit death via p $75^{\text {NTR }}$ activation (Bamji et al., 1998). Neuronal apoptosis was assessed for each culture condition $48 \mathrm{~h}$ later. The

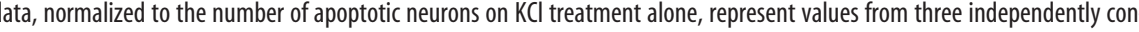
experiments. The vertical error bars indicate SEM. Note that membrane depolarization prevented NGF-deprived neuron death (Franklin et al., 1995), but not did not affect proNT-3-induced apoptosis. For $\boldsymbol{A}-\boldsymbol{D}$, asterisks denote statistical significance

As expected from past findings (Harris et al., 2002; Xu et al., 2003), inhibition of JNK activity was found to rescue NGFdeprived sympathetic neurons from dying.

Together, our data from Figures 5-7 have identified JNK as a signaling component downstream of proNT-3-induced cell death and support the hypothesis that proNT- 3 uses $\mathrm{p} 75^{\mathrm{NTR}}$ to initiate neuronal apoptotic cascade. Unlike that reported for mature NT-3 (Friedman, 2000; Wang et al., 2000), subnanomolar concentrations of proNT-3 are sufficient to activate apoptotic signaling. Therefore, proNT-3 appears to be a high-affinity proapoptotic ligand for the sympathetic neurons.

\section{Retrograde proapoptotic actions of proNT-3}

Retrograde survival signaling is a hallmark feature of the neurotrophin hypothesis (Zweifel et al., 2005; Ibáñez, 2007). Although NT-3 is not effectively taken up at the axonal termini of young SCG neurons (Kuruvilla et al., 2004), anti-NT-3 immunoreactivities in peripheral tissues, including targets of sympathetic innervation, far exceed that in the nervous system (Kaisho et al., 1994; Katoh-Semba et al., 1996) (Fig. 2A). In non-neuronal cell lines, inhibition of proNT-3 cleavage can result in its release instead of 

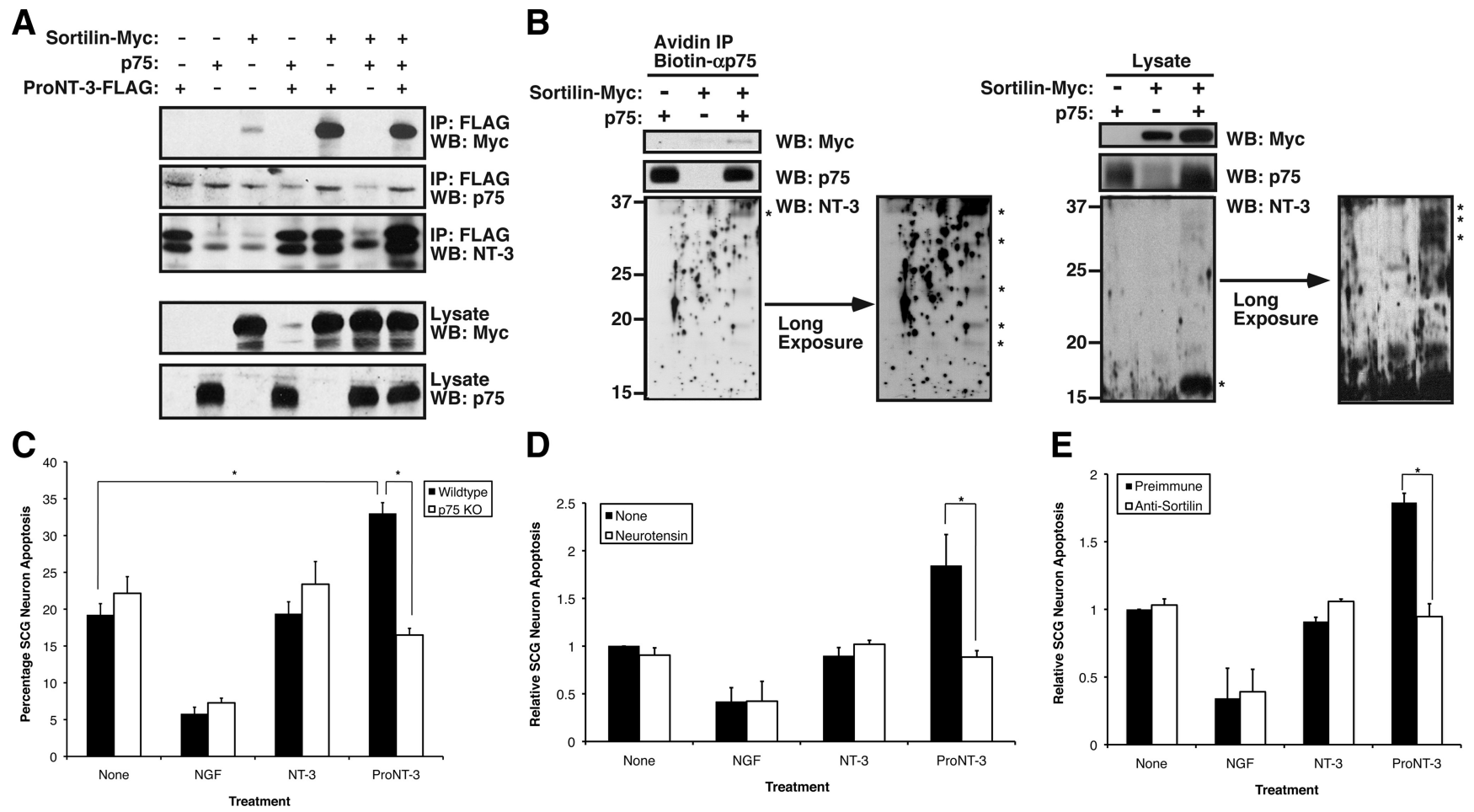

D

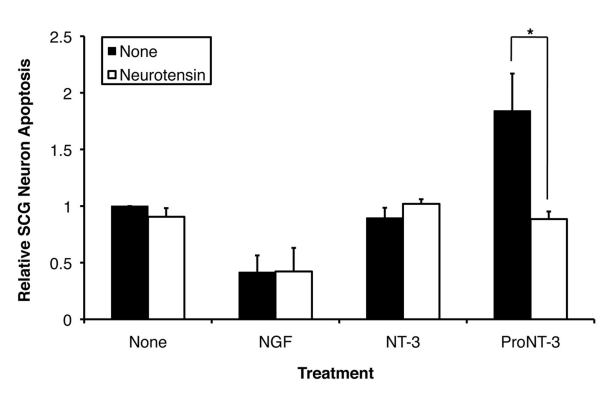

E

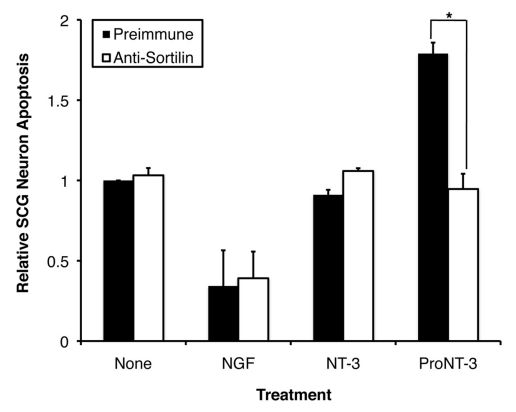

Figure 6. Dual-receptor requirement for ProNT-3 action. A, Coimmunoprecipitation of proNT-3 and sortilin. HEK 293T cells were transfected with Myc-tagged sortilin, p75 NTR, FLAG-tagged proNT-3 alone or in combination as indicated. Forty-eight hours later, detergent lysates were immunoprecipitation with anti-FLAG beads (Sigma-Aldrich), followed by Western blotting analysis with anti-NT-3, anti-p75 ${ }^{\text {NTR }}$, or anti-Myc antisera as indicated. Note that sortilin but not p75 ${ }^{\text {NTR }}$ readily coimmunoprecipitated with proNT-3 and that stable complex between sortilin and proNT-3 was not enhanced by $\mathrm{p} 75^{\mathrm{NTR}}$. B, Sortilin expression is required for proNT-3 binding to $\mathrm{p} 75^{\mathrm{NTR}}$. HEK $293 \mathrm{~T}$ cells were transiently transfected with either p $75^{\mathrm{NTR}}$, Myc-tagged sortilin, or both receptors as indicated. Forty-eight hours later, exogenous recombinant proNT-3 (for proNT-3 production in $293 \mathrm{~T}$ cells, see Fig. 3A) was added to these cells for 1 h. Left panel, Anti-p75 NTR immunoprecipitation was performed as described (see Materials and Methods), followed by Western blotting for proNT-3 (anti-NT3), sortilin (anti-Myc), and p75 ${ }^{\text {NTR }}$. Right panel, The corresponding total cellular lysates were similarly Western blotted with the indicated antisera. Note that proNT-3 internalization, which occurred only in cells that coexpress both p $75^{\mathrm{NTR}}$ and sortilin, also resulted in significant degradation of the molecule. The numbers on the left indicate positions of the molecular weight markers. The asterisks ${ }^{*}$ ) on the left indicate full-length proNT-3 ( $\sim 37 \mathrm{kDa}$ ) and various partially cleaved NT-3 species ( 32-16 kDa). Note also that, in these experiments, no mature NT-3 of the expected molecular weight (i.e., $13 \mathrm{kDa}$ ) was detected, suggesting that endocytosed proNT-3 is not processed by the same furin-based mechanism for mature NT-3 production. C, p $75^{\mathrm{NTR}}$ is required for proNT-3-induced neuronal apoptosis. Wild-type or p75 ${ }^{\mathrm{NTR}}$-null SCG neurons were cultured as described previously (Nykjaer et al., 2004; Teng et al., 2005). Replica cultures (DIV 7), washed free of NGF, were treated or not with $10 \mathrm{ng} / \mathrm{ml} \mathrm{NGF} \mathrm{or} \mathrm{equal} \mathrm{molar} \mathrm{of} \mathrm{NT-3} \mathrm{or} \mathrm{proNT-3} \mathrm{(i.e.,} 2$ ng/mI NT-3 or $4 \mathrm{ng} / \mathrm{ml} \mathrm{proNT}-3$ ) as indicated. The percentage of apoptotic neurons were assessed $36 \mathrm{~h}$ later. The data were not further normalized because neurons for these experiments were from $\mathrm{tw}$ o different sources (i.e., wild-type and p $75^{\text {NTR }}$-null mice). The vertical error bars indicate SEM $(n=5)$. D, Sortilin antagonist neurotensin abrogates proNT-3 induced SCG apoptosis. NGF-deprived rat SCG neuron cultures were treated with no ligand (None), $10 \mathrm{ng} / \mathrm{ml} \mathrm{NGF}$, or equal molar of NT-3 or proNT-3 (i.e., $2 \mathrm{ng} / \mathrm{ml} \mathrm{NT}-3 \mathrm{or} 4 \mathrm{ng} / \mathrm{ml}$ proNT-3) in the presence or absence of $20 \mu \mathrm{m}$ neurotensin as indicated. Neuronal apoptosis under each culture condition was evaluated $48 \mathrm{~h}$ later, and the data were normalized to that of apoptotic neurons without any trophic factor or neurotensin treatment. Data represent the results obtained from three independently conducted experiments. The vertical error bars indicate SEM. $E$, Sortilin antiserum blocks apoptosis of proNT-3-treated SCG neurons. NGF-deprived rat SCG neuron cultures were treated with $10 \mathrm{ng} / \mathrm{ml} \mathrm{NGF}$ or equal molar of NT-3 or proNT-3 (i.e., $2 \mathrm{ng} / \mathrm{ml} \mathrm{NT}-3$ or $4 \mathrm{ng} / \mathrm{ml}$ proNT-3) in the presence of an anti-sortilin antiserum (1:10 dilution) or the equivalent dilution of preimmune serum as a control (for characterization of the antiserum, see supplemental Fig. 1, available at www.jneurosci.org as supplemental material). Neuronal apoptosis under each culture condition was evaluated $48 \mathrm{~h}$ later. The data represent the results obtained from three independently conducted experiments. The vertical error bars indicate SEM. Note that sortilin antiserum specifically inhibits proNT-3-induced cell killing without additional survival-promoting effects on NGF-deprived neurons. For $\boldsymbol{C}-\boldsymbol{E}$, asterisks denote statistical significance between the paired samples.

mature NT-3 (Seidah et al., 1996; Farhadi et al., 2000) (Fig. 3). We therefore considered the possibility that proNT-3, if secreted from target tissues, might be deleterious to the ganglia innervating these sites.

Retrograde neuronal signaling can be studied in vitro in compartmentalized cultures in which the neuronal cell bodies are segregated from the distal axons (Fig. 8A) (MacInnis and Campenot, 2002; Ye et al., 2003). To test whether proNT-3 can elicit neuronal cell death from the distal axons, we selectively applied proNT-3 or mature NT-3 to this compartment while neuronal cell bodies continued to receive NGF for trophic support. Conversely, we treated distal axons with NGF but cell bodies with proNT-3 or NT-3. Neuronal death was assessed $2 \mathrm{~d}$ later by the presence of condensed or fragmented nuclei as revealed by DAPI staining following published techniques (Fig. 8 B) (Ye et al., 2003). Consistent with past findings, NGF applied to the center and distal compartments maintained neuronal survival (MacInnis and Campenot, 2002; Ye et al., 2003). In contrast, simultaneous treatment of both compartments with proNT-3 elicited cell death, consistent with our mass culture data above. Mature NT-3, when used at low concentration $(10 \mathrm{ng} / \mathrm{ml})$, did not elicit any appreciable survival-promoting or apoptotic effect. Intriguingly, we found that proNT-3, applied to the distal axons alone, effectively induced sympathetic neuron death even when neuronal cell bodies continued to receive trophic support from NGF (Fig. 8C). These observations therefore suggest that proNT-3 can initiate apoptotic signaling locally, which propagates back to the neuronal cell bodies.

It is also important to note that NGF applied to the distal axons did not rescue sympathetic neuron death that was triggered by proNT-3 present exclusively in the cell body compartment (Fig. 8C). Under this paradigm, neuronal cell bodies continued to 
receive trophic support from the distal NGF-treated axons both before and during proNT-3 application to the cell bodies. Therefore, it is unlikely that the survival signal from distally applied NGF did not arrive "in time" to rescue these neurons. These results suggest that the retrograde survival-promoting effects of NGF can be overcome by local apoptotic signal located at the cell body.

\section{Discussion}

The roles of proNT-3 have not been extensively studied. Using recombinant proNT-3 in which the furin/proconvertase cleavage consensus has been mutated to prevent the conversion to mature NT-3, we report here that proNT-3 is a proapoptotic ligand for specific neural populations such as SCGs (Fig. 5) and DRGs (supplemental Fig. 2, available at www.jneurosci.org as supplemental material). This action requires the coreceptor complex of $\mathrm{p} 75^{\mathrm{NTR}}$ and sortilin and downstream JNK signaling (Fig. 7), similar to how proNGF and proBDNF induce neuronal apoptosis (Nykjaer et al., 2004; Teng et al., 2005; Volosin et al., 2006). Interestingly, $\gamma$-secretase-dependent cleavage of $\mathrm{p} 75^{\mathrm{NTR}}$ has been shown as a causal trigger for proBDNF-induced sympathetic neuron death (Kenchappa et al., 2006). Future studies are needed to determine whether all proneurotrophins or neurotrophins use a similar p75 ${ }^{\mathrm{NTR}}$ dependent mechanism for signal transduction (Kenchappa et al., 2006; Bertrand et al., 2008; Vilar et al., 2009a,b). The complexity of neurotrophin signaling through p $75^{\text {NTR }}$, however, can be gleaned from early binding and mutagenesis studies (Rodríguez-Tébar et al., 1992; Rydén et al., 1995; Urfer et al., 1995), as well as recent crystal structures of NGF:p75 ${ }^{\text {NTR }}$ and NT-3:p75 ${ }^{\text {NTR }}$ (He and Garcia, 2004; Gong et al., 2008). One conclusion from these collective works is that there are significant differences between two structurally related ligands in their interactions with p $75^{\text {NTR }}$. Presumably, the binding of the neurotrophin prodomain to sortilin will further influence how $\mathrm{p} 75^{\mathrm{NTR}}$ signals during normal development (Woo et al., 2005; Nakamura et al., 2007; Singh et al., 2008) and in pathological conditions (Volosin et al., 2006; Al-Shawi et al., 2008).

A surprising aspect of our study is the finding that proNT-3 can induce neuronal death when it is present exclusively at the distal axons, implicating some form of retrograde death signaling to the soma. Previous analysis of TrkA-dependent tro-
A

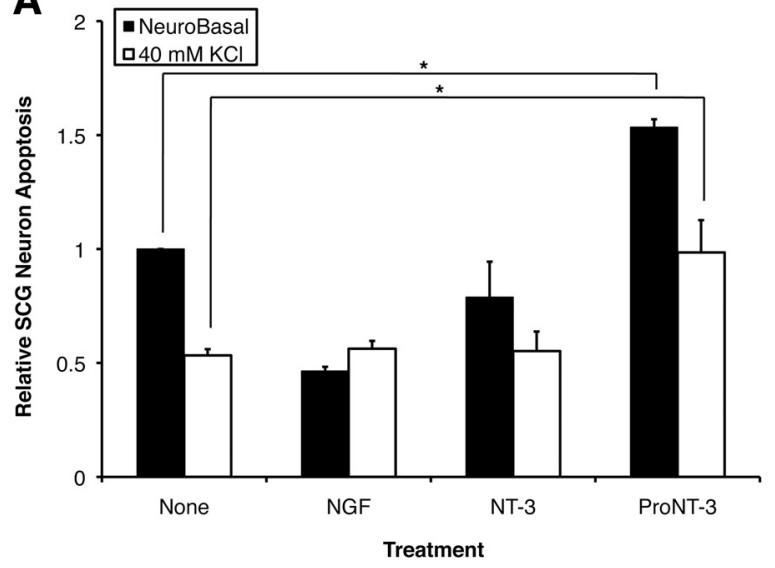

B
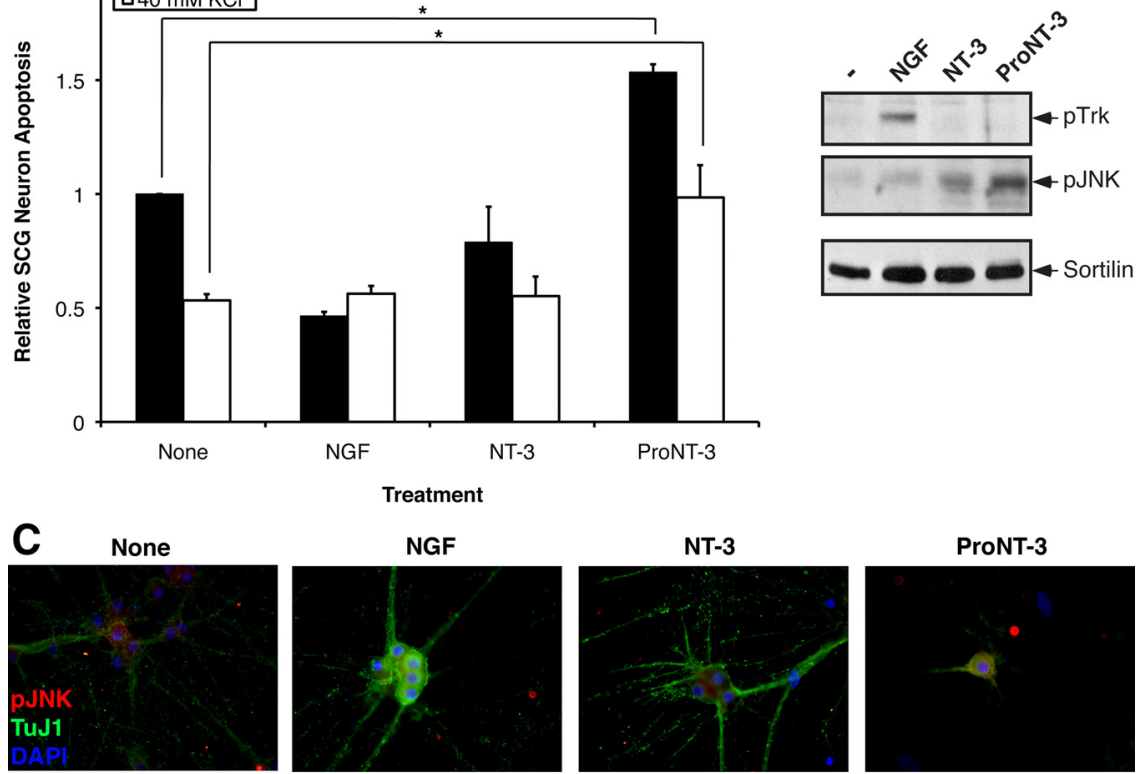

NGF
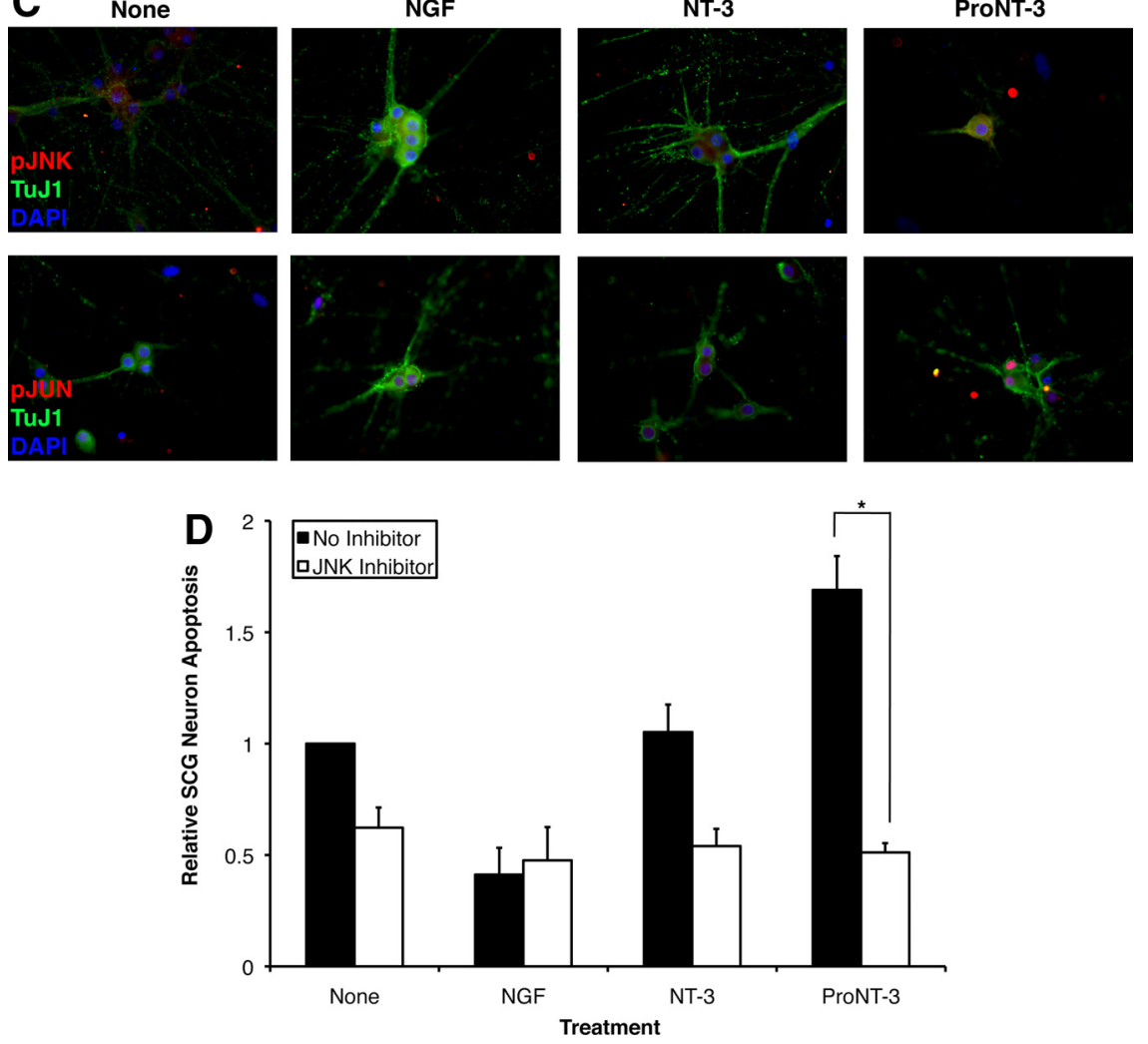

Figure 7. A role for JNK in proNT-3-induced neuronal apoptosis. $A$, Replica cultures of rat SCG neurons (DIV 7) were washed free of NGF and were treated or not with $10 \mathrm{ng} / \mathrm{ml} \mathrm{NGF}$ or equal molar NT-3 or proNT-3 (i.e., $2 \mathrm{ng} / \mathrm{ml} \mathrm{NT}-3$ or $4 \mathrm{ng} / \mathrm{ml}$ proNT-3) in the presence or absence of $40 \mathrm{~mm} \mathrm{KCl}$ as indicated. Neuronal apoptosis was assessed for each culture condition $48 \mathrm{~h}$ later. The data, normalized to the number of apoptotic neurons on NGF deprivation, represent values from three independently conducted experiments. The vertical error bars indicate SEM. Note that membrane depolarization prevented NGF-deprived neuron death (Franklin et al., 1995) but not did not affect proNT-3-induced apoptosis. B, Replica cultures of rat SCG neurons (DIV 7) were washed free of NGF and were then treated with $12.5 \mathrm{~mm} \mathrm{KCl}$ as described for analysis of JNK activation (Linggi et al., 2005). SCG neurons were treated or not with $50 \mathrm{ng} / \mathrm{ml} \mathrm{NGF,} 25 \mathrm{ng} / \mathrm{ml}$ mature NT-3, or $25 \mathrm{ng} / \mathrm{ml}$ proNT-3 as indicated for $4 \mathrm{~h}$. Cellular lysates (100 $\mu \mathrm{g}$ each) were Western blotted with the indicated antisera to assess proNT-3-induced JNK activation relative to TrkA-specific signaling. Equality of sample loading was verified by reprobing the blot with an anti-sortilin antiserum (BD Biosciences). C, Replica cultures of P1 SCG neurons (DIV 7) were washed free of NGF and maintained in $12.5 \mathrm{~mm} \mathrm{KCl} \mathrm{either} \mathrm{in} \mathrm{presence} \mathrm{or} \mathrm{absence} \mathrm{of} \mathrm{NGF,} \mathrm{NT-3,} \mathrm{or} \mathrm{proNT-3} \mathrm{as} \mathrm{indicated.} \mathrm{Forty-eight} \mathrm{hours}$ later, cells were fixed and stained with TuJ1 (Covance), pJNK (Cell Signaling), and DAPI as indicated. Only proNT-3-treated, apoptotic neurons exhibited pJNK immunoreactivity (top panels). Alternatively, cultures were stained with TuJ1 and pJun as corroborative evidence of JNK activation (bottom panels). D, Replica cultures of rat SCG neurons (DIV 7) were washed free of NGF and were treated or not with $10 \mathrm{ng} / \mathrm{ml} \mathrm{NGF}$ or equal molar of NT-3 or proNT-3 (i.e., $2 \mathrm{ng} / \mathrm{ml} \mathrm{NT}-3$ or $4 \mathrm{ng} / \mathrm{ml}$ proNT-3) in the presence or absence of $15 \mu \mathrm{m}$ SP600125 as indicated. Neuronal apoptosis under standard (non-depolarizing) culture condition were assessed $48 \mathrm{~h}$ after treatment. The data, normalized to the number of apoptotic neurons on NGF deprivation, represent values from three independently conducted experiments, and the vertical error bars indicate SEM. For $A$ and $D$, asterisks denote statistical significance between the paired samples. 
A

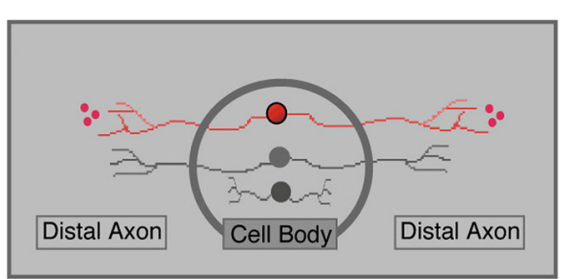

B

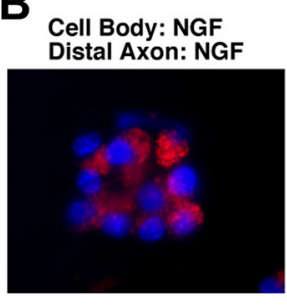
Cell Body: ProNT-3
Distal Axon: ProNT-3

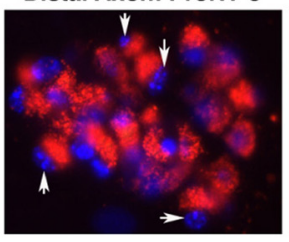

C

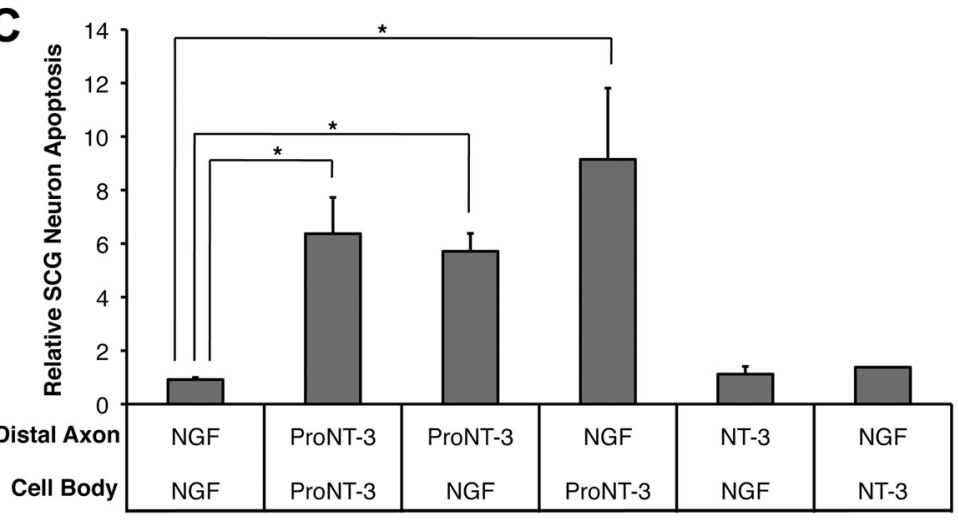

Treatment

Figure 8. Retrograde apoptotic signaling. $\boldsymbol{A}$, Schematic representation of compartmentalized culture system. Only neurons (red) that were prelabeled with fluorescent microspheres were evaluated in subsequent analysis. $\boldsymbol{B}$, Fluorescent photomicrograph of SCG neurons under the indicated culture conditions. Only viable neurons with active retrograde transport take up fluorescent microspheres from the distal axon compartment. The arrows indicate fragmented nuclei of dying neurons. $\boldsymbol{C}_{\text {, Assessment of }}$ neuronal apoptosis under each culture conditions. Replica compartmentalized cultures were treated with $1 \mathrm{ng} / \mathrm{ml} \mathrm{NGF}$ or equal molar of NT-3 or proNT-3 (i.e., $5 \mathrm{ng} / \mathrm{ml} \mathrm{NT-3} \mathrm{or} 10 \mathrm{ng} / \mathrm{ml} \mathrm{proNT-3)} \mathrm{in} \mathrm{the} \mathrm{center} \mathrm{cell} \mathrm{body} \mathrm{compartment} \mathrm{as} \mathrm{indicated,} \mathrm{whereas} 10$ $\mathrm{ng} / \mathrm{ml} \mathrm{NGF}$ or equal molar of NT-3 or proNT-3 (i.e., $5 \mathrm{ng} / \mathrm{ml} \mathrm{NT}-3$ or $10 \mathrm{ng} / \mathrm{ml}$ proNT-3) was applied to the distal axon compartment. Neuronal apoptosis was evaluated $48 \mathrm{~h}$ later. The data, normalized to the number of apoptotic neurons maintained with NGF in both compartments, were pooled from five independently conducted experiments. The vertical error bars indicate SEM. Asterisks denote statistical significance between the paired samples.

phic signaling suggests that specific cellular events can be triggered by NGF at the distal axons, which propagate back to the neuronal cell bodies (Howe and Mobley, 2005; Zweifel et al., 2005). Whether proNT-3 recruits distinct cellular components for its retrograde apoptotic actions, as has been recently demonstrated for sympathetic neurons on NGF deprivation at the axonal termini (Mok et al., 2009), remains an intriguing possibility. Nevertheless, it is interesting to note that NGF effectively rescued proNT-3-treated neuron from death in mass culture (Fig. 5B) but was unable to prevent SCG apoptosis when presented in distinct compartment from proNT-3 (Fig. 8C). These observations therefore suggest that the ability of NGF to "terminate" proNT-3initiated apoptotic cascade depends on whether prosurvival signaling (presumably via TrkA activation) occurs in the same membrane proximal location.

Sympathetic neurons of the superior cervical ganglia do not retrogradely transport NT-3 (DiStefano et al., 1992; Reynolds and Hendry, 1999; Kuruvilla et al., 2004). Rather, NT-3 acts via TrkA locally on nascent axons to promote process outgrowth (Kuru-
Cell Body: NGF Distal Axon: ProNT-3

Cell Body: ProNT-3 Distal Axon: NGF

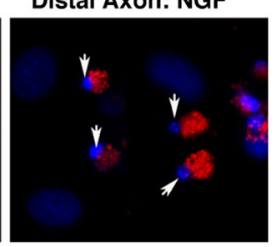

villa et al., 2004). Thus, our finding that proNT-3 elicits apoptotic signaling from the distal axons distinguishes this ligand with the localized effects of mature NT-3 in biological significance. Specifically, since perturbation of proNT-3 processing results in proNT-3 release instead of mature NT-3 (Fig. 3A) (Seidah et al., 1996; Farhadi et al., 2000), it is conceivable that neurodegeneration can be caused by proNT-3 secretion, perhaps in addition to mature neurotrophins deprivation, from innervated targets. Given that multiple targets of peripheral innervation express high levels of NT-3 (Kaisho et al., 1994; Katoh-Semba et al., 1996), this paradigm might have broad implications in the etiology of neurodegenerative diseases that involve neurotrophin processing and release (Lessmann et al., 2003; Srinivasan et al., 2004; Bruno and Cuello, 2006; Domeniconi et al., 2007). Accordingly, the finding of proBDNF accumulation at sites of distal nerve crush (Wang et al., 2006) is consistent with the hypothesis that retrograde transport of proneurotrophins is a distinct cellular event on injury.

Although our data suggest that proNT-3 is an apoptotic ligand for peripheral neurons, we also documented activity-dependent endogenous proNT-3 secretion from cerebellar granule neurons. Since it is well known that membrane depolarization promotes cerebellar granule neurons survival (D'Mello et al., 1993), proNT-3 might play a distinct, nonapoptotic, role in the developing CNS. Indeed, the findings that proBDNF acts via $\mathrm{p} 75^{\mathrm{NTR}}$ to induce hippocampal longterm depression (Woo et al., 2005) and synaptic retraction at the neuromuscular synapses (Yang et al., 2009a) are consistent with such a possibility. Alternatively, since both secreted proNGF and proBDNF can be cleaved by extracellular proteinases (Pang et al., 2004; Bruno and Cuello, 2006) as well as by glia-dependent uptake and re-released as mature neurotrophins (Althaus and Klöppner, 2006; Bergami et al., 2008), proNT-3 might be subjected to similar mechanisms for localized processing to mature NT-3 to limit TrkC activation. Our finding that TrkC-expressing $\mathrm{PC} 12^{\mathrm{nnr} 5}$ cells remained somewhat responsive to proNT-3 is consistent with a model of proneurotrophin processing on endocytosis (Boutilier et al., 2008). Although our data indicate that mature NT-3 is present in greater abundance in the adult cerebellum (Fig. 2C), and are therefore consistent with a crucial role for TrkC in CNS development (Minichiello and Klein, 1996; von Bohlen und Halbach et al., 2003), future study will be required to understand the physiological significance of proNT-3 processing and release in relation to $\mathrm{p} 75^{\mathrm{NTR}}$ versus TrkC activation throughout development and in adulthood.

Past analysis has identified the dual roles of sortilin as an intracellular neurotrophin sorting molecule (Chen et al., 2005) and an extracellular proneurotrophin receptor (Nykjaer et al., 
2004; Teng et al., 2005). Our findings are consistent with the latter work and implicate sortilin as a p $75^{\mathrm{NTR}}$ coreceptor for proNT-3. Given the observation that proNT-3 prodomain cleavage can be uncoupled from the secretory pathway (Figs. 2, 3) (Seidah et al., 1996; Farhadi et al., 2000), elucidating the molecular interactions between proNT-3 and sortilin will be crucial to understand whether sortilin also modulates proNT-3 processing and release. Although sortilin is but one of several related Vps$10 \mathrm{p}$ domain-containing molecules (Hermans-Borgmeyer et al., 1998; Mazella, 2001; Hermey et al., 2004), our data using a sortilin antagonist (Fig. 6D) and an anti-sortilin blocking antiserum (Fig. 6E) strongly suggest that the apoptotic action of proNT-3 requires sortilin. Consistent with these findings, proNT-3 uptake in a surrogate cell line can only be reconstituted in the presence of sortilin and $\mathrm{p} 75^{\mathrm{NTR}}$ (Fig. $6 \mathrm{~B}$ ). However, we cannot rule out the possibility that in vivo where both $\mathrm{p} 75^{\mathrm{NTR}}$ and multiple sortilin family members are expressed at varying abundance and in different cell types, the specificity of proneurotrophin actions might be mediated by additional sortilin family members.

In summary, our study raises the intriguing possibility of proNT-3 as a target-derived apoptotic factor. Along with the reported role of truncated TrkC in mediating mature NT-3 actions (Esteban et al., 2006), NT-3 and its precursor proNT-3 are capable of eliciting a plethora of biological events that differ in terms of coreceptor use and mechanisms of downstream signaling, consistent with their widespread expressions in both neural and nonneural tissues.

\section{References}

Al-Shawi R, Hafner A, Olsen J, Olson J, Chun S, Raza S, Thrasivoulou C, Lovestone S, Killick R, Simons P, Cowen T (2008) Neurotoxic and neurotrophic roles of proNGF and the receptor sortilin in the adult and ageing nervous system. Eur J Neurosci 27:2103-2114.

Althaus HH, Klöppner S (2006) Mature pig oligodendrocytes rapidly process human recombinant pro-nerve growth factor and do not undergo cell death. J Neurochem 98:506-517.

Bamji SX, Majdan M, Pozniak CD, Belliveau DJ, Aloyz R, Kohn J, Causing CG, Miller FD (1998) The p75 neurotrophin receptor mediates neuronal apoptosis and is essential for naturally occurring sympathetic neuron death. J Cell Biol 140:911-923.

Bates B, Rios M, Trumpp A, Chen C, Fan G, Bishop JM, Jaenisch R (1999) Neurotrophin-3 is required for proper cerebellar development. Nat Neurosci 2:115-117.

Bergami M, Santi S, Formaggio E, Cagnoli C, Verderio C, Blum R, Berninger B, Matteoli M, Canossa M (2008) Uptake and recycling of pro-BDNF for transmitter-induced secretion by cortical astrocytes. J Cell Biol 183:213-221.

Bertrand MJ, Kenchappa RS, Andrieu D, Leclercq-Smekens M, Nguyen HN, Carter BD, Muscatelli F, Barker PA, De Backer O (2008) NRAGE, a p75NTR adaptor protein, is required for developmental apoptosis in vivo. Cell Death Differ 15:1921-1929.

Bibel M, Hoppe E, Barde YA (1999) Biochemical and functional interactions between the neurotrophin receptors trk and p75NTR. EMBO J 18:616-622.

Boutilier J, Ceni C, Pagdala PC, Forgie A, Neet KE, Barker PA (2008) Proneurotrophins require endocytosis and intracellular proteolysis to induce TrkA activation. J Biol Chem 283:12709-12716.

Bruno MA, Cuello AC (2006) Activity-dependent release of precursor nerve growth factor, conversion to mature nerve growth factor, and its degradation by a protease cascade. Proc Natl Acad Sci U S A 103:6735-6740.

Chen ZY, Ieraci A, Teng H, Dall H, Meng CX, Herrera DG, Nykjaer A, Hempstead BL, Lee FS (2005) Sortilin controls intracellular sorting of brain-derived neurotrophic factor to the regulated secretory pathway. J Neurosci 25:6156-6166.

Dechant G, Barde YA (2002) The neurotrophin receptor p75(NTR): novel functions and implications for diseases of the nervous system. Nat Neurosci 5:1131-1136.

DiStefano PS, Friedman B, Radziejewski C, Alexander C, Boland P, Schick
CM, Lindsay RM, Wiegand SJ (1992) The neurotrophins BDNF, NT-3, and NGF display distinct patterns of retrograde axonal-transport in peripheral and central neurons. Neuron 8:983-993.

D’Mello SR, Galli C, Ciotti T, Calissano P (1993) Induction of apoptosis in cerebellar granule neurons by low potassium: inhibition of death by insulin-like growth factor I and cAMP. Proc Natl Acad Sci U S A 90:10989-10993.

Domeniconi M, Hempstead BL, Chao MV (2007) Pro-NGF secreted by astrocytes promotes motor neuron cell death. Mol Cell Neurosci 34:271-279.

Eilers A, Whitfield J, Babij C, Rubin LL, Ham J (1998) Role of the Jun kinase pathway in the regulation of c-Jun expression and apoptosis in sympathetic neurons. J Neurosci 18:1713-1724.

Esteban PF, Yoon HY, Becker J, Dorsey SG, Caprari P, Palko ME, Coppola V, Saragovi HU, Randazzo PA, Tessarollo L (2006) A kinase-deficient TrkC receptor isoform activates Arf6-Racl signaling through the scaffold protein tamalin. J Cell Biol 173:291-299.

Farhadi HF, Mowla SJ, Petrecca K, Morris SJ, Seidah NG, Murphy RA (2000) Neurotrophin-3 sorts to the constitutive secretory pathway of hippocampal neurons and is diverted to the regulated secretory pathway by coexpression with brain-derived neurotrophic factor. J Neurosci 20:4059-4068.

Franklin JL, Sanz-Rodriguez C, Juhasz A, Deckwerth TL, Johnson EM Jr (1995) Chronic depolarization prevents programmed death of sympathetic neurons in vitro but does not support growth: requirement for $\mathrm{Ca}^{2+}$ influx but not Trk activation. J Neurosci 15:643-664.

Friedman WJ (2000) Neurotrophins induce death of hippocampal neurons via the p75 receptor. J Neurosci 20:6340-6346.

Gentry JJ, Barker PA, Carter BD (2004) The p75 neurotrophin receptor: multiple interactors and numerous functions. Prog Brain Res 146:25-39.

Gong Y, Cao P, Yu HJ, Jiang T (2008) Crystal structure of the neurotrophin-3 and p75NTR symmetrical complex. Nature 454:789-793.

Green SH, Rydel RE, Connolly JL, Greene LA (1986) PC12 cell mutants that possess low- but not high-affinity nerve growth factor receptors neither respond to nor internalize nerve growth factor. J Cell Biol 102:830-843.

Harrington AW, Kim JY, Yoon SO (2002) Activation of Rac GTPase by p75 is necessary for c-Jun N-terminal kinase-mediated apoptosis. J Neurosci 22:156-166.

Harris CA, Deshmukh M, Tsui-Pierchala B, Maroney AC, Johnson EM Jr (2002) Inhibition of the c-Jun N-terminal kinase signaling pathway by the mixed lineage kinase inhibitor CEP-1347 (KT7515) preserves metabolism and growth of trophic factor-deprived neurons. J Neurosci 22:103-113.

He XL, Garcia KC (2004) Structure of nerve growth factor complexed with the shared neurotrophin receptor p75. Science 304:870-875.

Hermans-Borgmeyer I, Hampe W, Schinke B, Methner A, Nykjaer A, Süsens U, Fenger U, Herbarth B, Schaller HC (1998) Unique expression pattern of a novel mosaic receptor in the developing cerebral cortex. Mech Dev 70:65-76.

Hermey G, Plath N, Hübner CA, Kuhl D, Schaller HC, Hermans-Borgmeyer I (2004) The three sorCS genes are differentially expressed and regulated by synaptic activity. J Neurochem 88:1470-1476.

Howe CL, Mobley WC (2005) Long-distance retrograde neurotrophic signaling. Curr Opin Neurobiol 15:40-48.

Ibáñez CF (2007) Message in a bottle: long-range retrograde signaling in the nervous system. Trends Cell Biol 17:519-528.

Jansen P, Giehl K, Nyengaard JR, Teng K, Lioubinski O, Sjoegaard SS, Breiderhoff T, Gotthardt M, Lin F, Eilers A, Petersen CM, Lewin GR, Hempstead BL, Willnow TE, Nykjaer A (2007) Roles for the proneurotrophin receptor sortilin in neuronal development, aging and brain injury. Nat Neurosci 10:1449-1457.

Kahn MA, Kumar S, Liebl D, Chang R, Parada LF, De Vellis J (1999) Mice lacking NT-3, and its receptor TrkC, exhibit profound deficiencies in CNS glial cells. Glia 26:153-165.

Kaisho Y, Shintani A, Nishida M, Fukumoto H, Igarashi K (1994) Developmental changes of neurotrophin-3 level in the mouse brain detected by a highly sensitive enzyme immunoassay. Brain Res 666:143-146.

Katoh-Semba R, Kaisho Y, Shintani A, Nagahama M, Kato K (1996) Tissue distribution and immunocytochemical localization of neurotrophin-3 in the brain and peripheral tissues of rats. J Neurochem 66:330-337.

Katoh-Semba R, Semba R, Takeuchi IK, Kato K (1998) Age-related changes 
in levels of brain-derived neurotrophic factor in selected brain regions of rats, normal mice and senescence-accelerated mice: a comparison to those of nerve growth factor and neurotrophin-3. Neurosci Res 31:227-234

Kenchappa RS, Zampieri N, Chao MV, Barker PA, Teng HK, Hempstead BL, Carter BD (2006) Ligand-dependent cleavage of the P75 neurotrophin receptor is necessary for NRIF nuclear translocation and apoptosis in sympathetic neurons. Neuron 50:219-232.

Kendall S, Yeo M, Henttu P, Tomlinson DR (2000) Alternative splicing of the neurotrophin-3 gene gives rise to different transcripts in a number of human and rat tissues. J Neurochem 75:41-47.

Klein M, Hempstead BL, Teng KK (2005) Activation of STAT5-dependent transcription by the neurotrophin receptor Trk. J Neurobiol 63:159-171.

Kuruvilla R, Zweifel LS, Glebova NO, Lonze BE, Valdez G, Ye H, Ginty DD (2004) A neurotrophin signaling cascade coordinates sympathetic neuron development through differential control of TrkA trafficking and retrograde signaling. Cell 118:243-255.

Lamballe F, Klein R, Barbacid M (1991) TrkC, a new member of the trk family of tyrosine protein kinases, is a receptor for neurotrophin-3. Cell 66:967-979.

Lee KF, Li E, Huber LJ, Landis SC, Sharpe AH, Chao MV, Jaenisch R (1992) Targeted mutation of the gene encoding the low affinity NGF receptor p75 leads to deficits in the peripheral sensory nervous system. Cell 69:737-749.

Lee R, Kermani P, Teng KK, Hempstead BL (2001) Regulation of cell survival by secreted proneurotrophins. Science 294:1945-1948.

Leingärtner A, Lindholm D (1994) Two promoters direct transcription of the mouse NT-3 gene. Eur J Neurosci 6:1149-1159.

Lessmann V, Gottmann K, Malcangio M (2003) Neurotrophin secretion: current facts and future prospects. Prog Neurobiol 69:341-374.

Lewin GR, Barde YA (1996) Physiology of the neurotrophins. Annu Rev Neurosci 19:289-317.

Lindholm D, Castrén E, Tsoulfas P, Kolbeck R, Berzaghi Mda P, Leingärtner A, Heisenberg CP, Tessarollo L, Parada LF, Thoenen H, Tesarollo L (1993) Neurotrophin-3 induced by tri-iodothyronine in cerebellar granule cells promotes Purkinje cell differentiation. J Cell Biol 122:443-450.

Linggi MS, Burke TL, Williams BB, Harrington A, Kraemer R, Hempstead BL, Yoon SO, Carter BD (2005) Neurotrophin receptor interacting factor (NRIF) is an essential mediator of apoptotic signaling by the p75 neurotrophin receptor. J Biol Chem 280:13801-13808.

Ma L, Harada T, Harada C, Romero M, Hebert JM, McConnell SK, Parada LF (2002) Neurotrophin-3 is required for appropriate establishment of thalamocortical connections. Neuron 36:623-634.

MacInnis BL, Campenot RB (2002) Retrograde support of neuronal survival without retrograde transport of nerve growth factor. Science 295:1536-1539.

Maisonpierre PC, Belluscio L, Squinto S, Ip NY, Furth ME, Lindsay RM, Yancopoulos GD (1990a) Neurotrophin-3: a neurotrophic factor related to NGF and BDNF. Science 247:1446-1451.

Maisonpierre PC, Belluscio L, Friedman B, Alderson RF, Wiegand SJ, Furth ME, Lindsay RM, Yancopoulos GD (1990b) NT-3, BDNF, and NGF in the developing rat nervous system: parallel as well as reciprocal patterns of expression. Neuron 5:501-509.

Mazella J (2001) Sortilin/neurotensin receptor-3: a new tool to investigate neurotensin signaling and cellular trafficking? Cell Signal 13:1-6.

Minichiello L, Klein R (1996) TrkB and TrkC neurotrophin receptors cooperate in promoting survival of hippocampal and cerebellar granule neurons. Genes Dev 10:2849-2858.

Mischel PS, Smith SG, Vining ER, Valletta JS, Mobley WC, Reichardt LF (2001) The extracellular domain of p75NTR is necessary to inhibit neurotrophin-3 signaling through TrkA. J Biol Chem 276:11294-11301.

Mok SA, Lund K, Campenot RB (2009) A retrograde apoptotic signal originating in NGF-deprived distal axons of rat sympathetic neurons in compartmented cultures. Cell Res 19:546-560.

Nagappan G, Zaitsev E, Senatorov VV Jr, Yang J, Hempstead BL, Lu B (2009) Control of extracellular cleavage of ProBDNF by high frequency neuronal activity. Proc Natl Acad Sci U S A 106:1267-1272.

Nakamura K, Namekata K, Harada C, Harada T (2007) Intracellular sortilin expression pattern regulates proNGF-induced naturally occurring cell death during development. Cell Death Differ 14:1552-1554.

Negro A, Tavella A, Grandi C, Skaper SD (1994) Production and character- ization of recombinant rat brain-derived neurotrophic factor and neurotrophin-3 from insect cells. J Neurochem 62:471-478.

Nykjaer A, Lee R, Teng KK, Jansen P, Madsen P, Nielsen MS, Jacobsen C, Kliemannel M, Schwarz E, Willnow TE, Hempstead BL, Petersen CM (2004) Sortilin is essential for proNGF-induced neuronal cell death. Nature 427:843-848.

Palmada M, Kanwal S, Rutkoski NJ, Gustafson-Brown C, Johnson RS, Wisdom R, Carter BD (2002) c-jun is essential for sympathetic neuronal death induced by NGF withdrawal but not by p75 activation. J Cell Biol 158:453-461.

Pang PT, Teng HK, Zaitsev E, Woo NT, Sakata K, Zhen S, Teng KK, Yung WH, Hempstead BL, Lu B (2004) Cleavage of proBDNF by tPA/plasmin is essential for long-term hippocampal plasticity. Science 306:487-491.

Quistgaard EM, Madsen P, Grøftehauge MK, Nissen P, Petersen CM, Thirup SS (2009) Ligands bind to Sortilin in the tunnel of a ten-bladed betapropeller domain. Nat Struct Mol Biol 16:96-98.

Randolph CL, Bierl MA, Isaacson LG (2007) Regulation of NGF and NT-3 protein expression in peripheral targets by sympathetic input. Brain Res 1144:59-69.

Reynolds AJ, Hendry IA (1999) A technique for ${ }^{125}$ I-labelling of neurotrophins and the use of retrograde axonal transport as a bioassay. Brain Res Brain Res Protoc 3:308-312.

Rodríguez-Tébar A, Dechant G, Götz R, Barde YA (1992) Binding of neurotrophin-3 to its neuronal receptors and interactions with nerve growth factor and brain-derived neurotrophic factor. EMBO J 11:917922.

Roux PP, Barker PA (2002) Neurotrophin signaling through the p75 neurotrophin receptor. Prog Neurobiol 67:203-233.

Rydén M, Murray-Rust J, Glass D, Ilag LL, Trupp M, Yancopoulos GD, McDonald NQ, Ibáñez CF (1995) Functional analysis of mutant neurotrophins deficient in low-affinity binding reveals a role for p75LNGFR in NT-4 signalling. EMBO J 14:1979-1990.

Sadakata T, Mizoguchi A, Sato Y, Katoh-Semba R, Fukuda M, Mikoshiba K, Furuichi T (2004) The secretory granule-associated protein CAPS2 regulates neurotrophin release and cell survival. J Neurosci 24:43-52.

Sadakata T, Kakegawa W, Mizoguchi A, Washida M, Katoh-Semba R, Shutoh F, Okamoto T, Nakashima H, Kimura K, Tanaka M, Sekine Y, Itohara S, Yuzaki M, Nagao S, Furuichi T (2007) Impaired cerebellar development and function in mice lacking CAPS2, a protein involved in neurotrophin release. J Neurosci 27:2472-2482.

Schecterson LC, Bothwell M (1992) Novel roles for neurotrophins are suggested by BDNF and NT-3 mRNA expression in developing neurons. Neuron 9:449-463.

Segal RA (2003) Selectivity in neurotrophin signaling: theme and variations. Annu Rev Neurosci 26:299-330.

Seidah NG, Benjannet S, Pareek S, Chrétien M, Murphy RA (1996) Cellular processing of the neurotrophin precursors of NT3 and BDNF by the mammalian proprotein convertases. FEBS Lett 379:247-250.

Singh KK, Park KJ, Hong EJ, Kramer BM, Greenberg ME, Kaplan DR, Miller FD (2008) Developmental axon pruning mediated by BDNF-p75NTRdependent axon degeneration. Nat Neurosci 11:649-658.

Srinivasan B, Roque CH, Hempstead BL, Al-Ubaidi MR, Roque RS (2004) Microglia-derived pronerve growth factor promotes photoreceptor cell death via p75 neurotrophin receptor. J Biol Chem 279:41839-41845.

Teng HK, Teng KK, Lee R, Wright S, Tevar S, Almeida RD, Kermani P, Torkin R, Chen ZY, Lee FS, Kraemer RT, Nykjaer A, Hempstead BL (2005) ProBDNF induces neuronal apoptosis via activation of a receptor complex of p75NTR and sortilin. J Neurosci 25:5455-5463.

Teng KK, Hempstead BL (2004) Neurotrophins and their receptors: signaling trios in complex biological systems. Cell Mol Life Sci 61:35-48.

Unsicker K, Stögbauer F (1992) Screening of adrenal medullary neuropeptides for putative neurotrophic effects. Int J Dev Neurosci 10:171-179.

Urfer R, Tsoulfas P, O'Connell L, Shelton DL, Parada LF, Presta LG (1995) An immunoglobulin-like domain determines the specificity of neurotrophin receptors. EMBO J 14:2795-2805.

Vilar M, Charalampopoulos I, Kenchappa RS, Simi A, Karaca E, Reversi A, Choi S, Bothwell M, Mingarro I, Friedman WJ, Schiavo G, Bastiaens PI, Verveer PJ, Carter BD, Ibáñez CF (2009a) Activation of the p75 neurotrophin receptor through conformational rearrangement of disulphidelinked receptor dimers. Neuron 62:72-83.

Vilar M, Charalampopoulos I, Kenchappa RS, Reversi A, Klos-Applequist JM, Karaca E, Simi A, Spuch C, Choi S, Friedman WJ, Ericson J, Schiavo G, 
Carter BD, Ibáñez CF (2009b) Ligand-independent signaling by disulfide-crosslinked dimers of the p75 neurotrophin receptor. J Cell Sci 122:3351-3357.

Volosin M, Song W, Almeida RD, Kaplan DR, Hempstead BL, Friedman WJ (2006) Interaction of survival and death signaling in basal forebrain neurons: roles of neurotrophins and proneurotrophins. J Neurosci 26:77567766.

Volosin M, Trotter C, Cragnolini A, Kenchappa RS, Light M, Hempstead BL, Carter BD, Friedman WJ (2008) Induction of proneurotrophins and activation of p75NTR-mediated apoptosis via neurotrophin receptorinteracting factor in hippocampal neurons after seizures. J Neurosci 28:9870-9879.

von Bohlen und Halbach O, Minichiello L, Unsicker K (2003) Haploinsufficiency in trkB and/or trkC neurotrophin receptors causes structural alterations in the aged hippocampus and amygdala. Eur J Neurosci 18:2319-2325.

Wang H, Wu LL, Song XY, Luo XG, Zhong JH, Rush RA, Zhou XF (2006) Axonal transport of BDNF precursor in primary sensory neurons. Eur J Neurosci 24:2444-2452.

Wang S, Bray P, McCaffrey T, March K, Hempstead BL, Kraemer R (2000) p75(NTR) mediates neurotrophin-induced apoptosis of vascular smooth muscle cells. Am J Pathol 157:1247-1258.

Willnow TE, Petersen CM, Nykjaer A (2008) VPS10P-domain receptors- regulators of neuronal viability and function. Nat Rev Neurosci 9: 899-909.

Woo NH, Teng HK, Siao CJ, Chiaruttini C, Pang PT, Milner TA, Hempstead BL, Lu B (2005) Activation of p75NTR by proBDNF facilitates hippocampal long-term depression. Nat Neurosci 8:1069-1077.

Xu Z, Kukekov NV, Greene LA (2003) POSH acts as a scaffold for a multiprotein complex that mediates JNK activation in apoptosis. EMBO J 22:252-261.

Yang F, Je HS, Ji Y, Nagappan G, Hempstead B, Lu B (2009a) Pro-BDNFinduced synaptic depression and retraction at developing neuromuscular synapses. J Cell Biol 185:727-741.

Yang J, Siao CJ, Nagappan G, Marinic T, Jing D, McGrath K, Chen ZY, Mark W, Tessarollo L, Lee FS, Lu B, Hempstead BL (2009b) Neuronal release of proBDNF. Nat Neurosci 12:113-115.

Ye H, Kuruvilla R, Zweifel LS, Ginty DD (2003) Evidence in support of signaling endosome-based retrograde survival of sympathetic neurons. Neuron 39:57-68.

Yoon SO, Casaccia-Bonnefil P, Carter B, Chao MV (1998) Competitive signaling between TrkA and p75 nerve growth factor receptors determines cell survival. J Neurosci 18:3273-3281.

Zhang SH, Zhou XF, Rush RA (2001) Extraction and quantification of the neurotrophins. Methods Mol Biol 169:31-41.

Zweifel LS, Kuruvilla R, Ginty DD (2005) Functions and mechanisms of retrograde neurotrophin signalling. Nat Rev Neurosci 6:615-625. 